\title{
Synthesis of Novel Pinocembrin Amino Acid Derivatives and Their Antiaging Effect on Caenorhabditis elegans via the Modulating DAF-I6/FOXO
}

\author{
Wenqi Wang* \\ Xin Feng* \\ Yu Du \\ Cen Liu \\ Xinxin Pang \\ Kunxiu Jiang \\ Xirui Wang \\ Yonggang Liu
}

School of Chinese Materia Medica, Beijing University of Chinese Medicine, Beijing,

102488, People's Republic of China

*These authors contributed equally to this work

\begin{abstract}
Purpose: Pinocembrin is a dihydroflavonoid, which is widely found in several plant species. Although pinocembrin has good pharmacological activity, it has poor water solubility and low bioavailability. Therefore, we have modified the structure of pinocembrin with a combination of different amino acids to solve this problem. Moreover, the effect of the antiaging activity of them has not been explored. We aim to investigate the effect of pinocembrin and its amino acid derivatives on the aging of Caenorhabditis elegans.
\end{abstract}

Methods: Pinocembrin was spliced with different amino acids in order to obtain their corresponding derivatives. The preliminary research of pinocembrin and its amino acid derivatives on antiaging effect was studied by using the $C$. elegans model. Among all the compounds, the one shows the best antiaging effect was then studied on antiaging mechanism. The protective effect on nematodes under emergency conditions was explained by detecting the ROS content and sod-3p::GFP fusion protein expression in nematodes; the possible anti-aging mechanism of nematodes was determined by DAF-16 nuclear localization experiment and the survival curve of transgenic nematodes model under stress conditions.

Results: Pb-3 showed the best effect on increasing tolerance to thermal and oxidative stress and reduce the accumulation of lipofuscin. In the assay of $C$. elegans, pb-3 reduced intracellular ROS accumulation. Application of pb-3 to the transgenic mutant TJ356 induced the translocation of the transcription factor DAF-16 from the cytosol to the nucleus, and modulated the expression of SOD-3 (downstream genes of daf-16), which regulates longevity in C. elegans. Moreover, pb-3 did not prolong the lifespan of daf-16, age-1, daf-2 and hsp16.2 mutants, suggesting that these genetic pathways are involved in mediating the antiaging effects of pb-3.

Conclusion: The antioxidant and antiaging properties of pb-3 may involve in the DAF-16/ FOXO transcription process. Pinocembrin amino acid derivatives might be a novel agent for antiaging therapy.

Keywords: pinocembrin, antiaging, oxidative stress, amino acid derivatives, Caenorhabditis elegans, DAF-16/FOXO transcription factors

\section{Introduction}

Aging is an inevitable biological process that occurs in every living organism including human being. Aging is considered as a primary risk factor for the development of many human diseases, such as neurodegenerative disease, cancer,
Correspondence: Yonggang Liu Email liuyg0228@I63.com 
diabetes, or heart disease. ${ }^{1}$ Therefore, increasing attention has been given to anti-aging research, which is of great practical significance for the study of drugs that prevent aging. ROS is one of the major contributing factors which responsible for aging and age-related disorders, it is generated during aerobic respiration and several metabolic reactions. Importantly, the excessive production of ROS results in oxidative stress. ${ }^{2,3}$ In this context, medicinal plants provide a high diversity of natural products, which can be exploited as potential antiaging agents. Over 300 compounds have been reported in the literature, including 185 natural compounds (such as Resveratrol, Astragaloside IV, or Rutin), and 55 complexes or extracts from natural products, these compounds are possess significant antioxidant activities against oxidative stress. ${ }^{4-8}$

Pinocembrin (PB; 5,7-dihydroxyflavanone, $\mathrm{C}_{15} \mathrm{H}_{12} \mathrm{O}_{4}$ ), a natural flavonoid compound, has been discovered in several plants such as the numerous genera of the Piperaceae family, which comprises 14 genera and 1950 species that are reported to be rich source of pinocembrin. ${ }^{9}$ In fact, previous studies have shown that pinocembrin presents anti-inflammatory, antifungal, antioxidant, anticancer and anti-allergic activities. ${ }^{9-15}$ Moreover, pinocembrin has a neuroprotective effect against cerebral ischemic injury by reducing reactive oxygen species (ROS), protecting the blood-brain barrier, modulating mitochondrial function, and regulating apoptosis. ${ }^{16-22}$

Various of studies have found that the biological activities of the compound have been affected by introduction of amino acid groups. For example, using baicalein as the parent compound to synthesize novel neuroprotective agents by combination with amino acids, carboxamide derivatives are synthesized by the reaction of amino acids and phthalic anhydride, which shows better antibacterial activity, compared with baicalein shows derivatives of 3-aminomethylglaucine have shown higher radical scavenging activity than that of 3-aminomethylglaucine and glaucine. ${ }^{23-25}$ There are 24 small-molecule drugs have been approved by FDA in 2019, among all these drugs, 13 contain a residue of amino acids, di-amines or amino-alcohols, which are commonly considered to be derived from the parent amino acids. ${ }^{26}$ Therefore, modification of the structure of pinocembrin by introducing a fragment containing an amino acid residue probably lead to a generation of compounds with useful biological properties.

The free-living nematode C. elegans is an ideal model in genetic and antiaging studies because the full sequence of nematode is closely homologous to the human genome. Nematode has a small transparent body which is easy to observe, and the lifespan is also short (about three weeks), moreover, the cultivate of nematode is also easy to handle. ${ }^{27}$ Since aging is characterized by progressive degenerative changes in tissue organization and functions, the feasibility of measuring age-related changes in neuromuscular behaviors such as pharyngeal pumping and biochemicals such as the accumulation of lipofuscin, are additional advantages of C. elegans. ${ }^{28}$

To understand the effects of pinocembrin amino acid derivatives, we performed experiments with the nematode model C. elegans. Pinocembrin is thought to have various of effects on preventing many diseases, we explored whether it could counteract aging or improve the lifespan of $C$. elegans. Another objective of the study is to determine whether pinocembrin derivatives would be more effective antiaging effects. To answer these questions, the following experiments were carried out to explore the effect of pinocembrin amino acid derivatives on the nematode model C. elegans.

\section{Materials and Methods}

\section{C. elegans Strains and Culture Conditions}

C. elegans strains were acquired from the Caenorhabditis Genetics Center (CGC, University of Minnesota, USA) including N2 (wild-type), CF1553 (muIs84 [(pAD76) sod-3::GFP)]), DR26 daf-16 (m26), TJ356 (zIs356[daf16p::daf-16a/b::GFP+rol-6]), VC475 hsp-16.2 (gk249), CB1370 daf-2 (e1370) III and TJ1052 age-1 (hx546). All the strains were maintained on nematode growth medium (NGM) plates seeded with E. coli OP50 for the entire experiment.

\section{Chemistry}

Scheme 1 Synthesis of the pinocembrin derivatives (Figure 1). Reagents and conditions: boc-amino acids, dichloromethane (DCM), 4-dimethylaminopyridine (DMAP), 1-ethyl-3-(3-dimethylaminopropyl) carbodiimide hydrochloride (EDCI); $25^{\circ} \mathrm{C} ; 12 \mathrm{~h}$.

The synthetic route is shown in Figure 2 (Boc-Gly-OH as an example), all the designed derivatives were synthesized following the procedures. The compound pinocembrin (1 equivalent (equiv.)) was dissolved in dry DCM (25 mL) and DMAP (0.5 equiv.), then the protected amino acid (1.2 equiv.) and EDCI (1.5 equiv.) were added in the solution, the mixture was stirred at $25{ }^{\circ} \mathrm{C}$ 


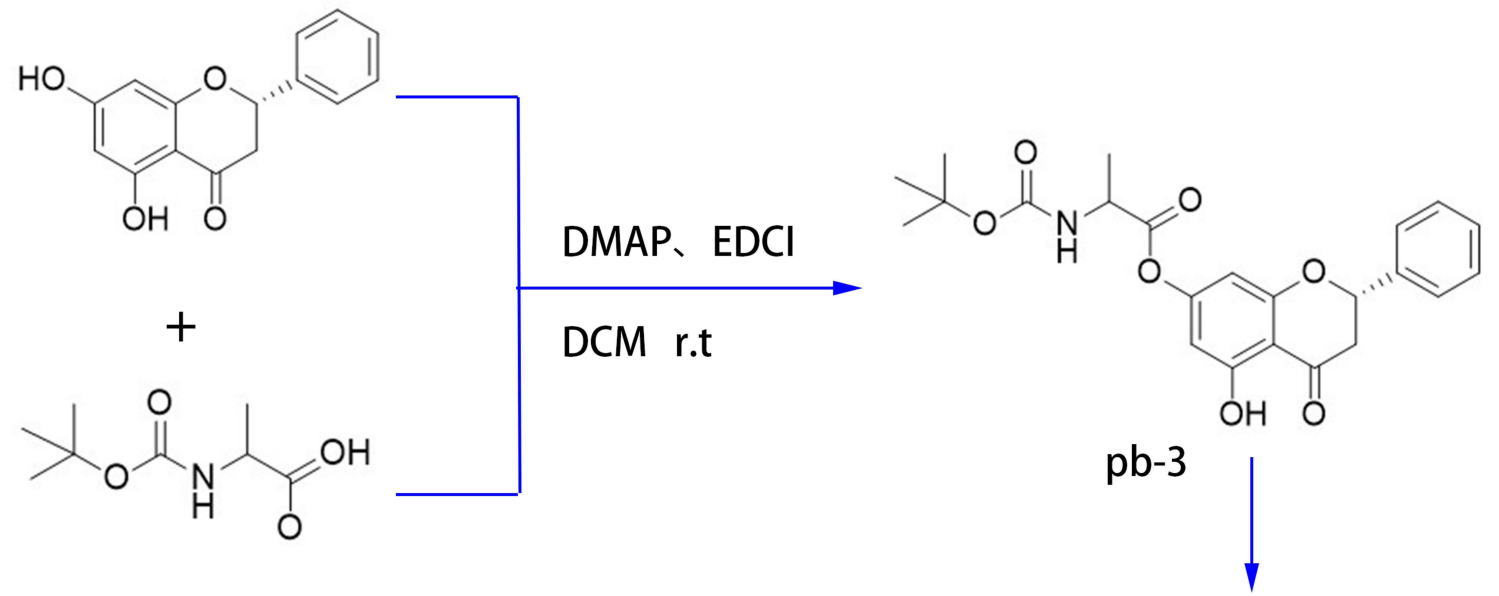

\section{The antioxidant and antiaging properties of pb-3 may involve in the DAF-16/FOXO transcription process}

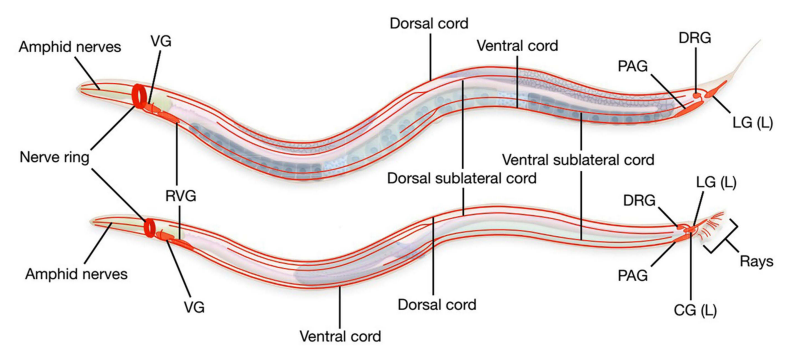

Scheme I Synthesis of the pinocembrin derivatives.

for $12 \mathrm{~h}$ under nitrogen gas. After completion of the reaction (as monitored by TLC), the solution was evaporated and washed with saturated sodium carbonate solution $(20 \mathrm{~mL})$. The aqueous layer was extracted with DCM $(25 \mathrm{~mL})$, and the combined organic extracts were washed with brine $(20 \mathrm{~mL})$, dried over sodium sulfate, filtered and evaporated. After concentrating by reduced pressure, a wet mixed compound was carried out on a silica gel column with dichloromethane and methanol as eluents for isocratic elution to purify the crude product.

2.2.1 (S)-5-Hydroxy-4-oxo-2-phenylchroman-7-yl (tert-butoxycarbonyl) phenylalaninate (pb-1) was obtained as yellow powder with a yield of $39.73 \% ;{ }^{1} \mathrm{H}-\mathrm{NMR}$ (400 MHz, DMSO- $d_{6}$, Figure S1-1) $\delta: 11.94(1 \mathrm{H}, \mathrm{s}, \mathrm{OH}-5)$, $7.63(1 \mathrm{H}, \mathrm{d}, J=7.0 \mathrm{~Hz}, \mathrm{CONH}), 7.53-7.55(2 \mathrm{H}, \mathrm{m}$, H-2', 6'), 7.40-7.47 (3H, m, H-3', 4', 5'), 7.24-7.31 $\left(5 \mathrm{H}, \mathrm{m}, \mathrm{Ph}-3^{\prime \prime}\right), 6.20(1 \mathrm{H}, \mathrm{s}, \mathrm{H}-8), 6.15(1 \mathrm{H}, \mathrm{s}, \mathrm{H}-6)$, 5.71-5.75 (1H, m, H-2), 4.34-4.39 (1H, m, H-2"), 3.393.47 (1H, m, H-3a), 3.01-3.13 (2H, m, H-3"), 2.88-2.92 $(1 \mathrm{H}, \mathrm{m}, \mathrm{H}-3 \mathrm{~b}), 1.36\left(9 \mathrm{H}, \mathrm{s},\left(\mathrm{CH}_{3}\right)_{3} \mathrm{C}\right) ;{ }^{13} \mathrm{C}-\mathrm{NMR}(100$ MHz, DMSO- $d_{6}$, Figure S1-2) $\delta: 197.5$ (C-4), 170.0 (C-1"), 162.1 (C-5), 162.0 (C-9), 157.8 (C-7), 155.4 (CONH), 138.1 (C-1'), 137.0 (C-1'"'), $129.1\left(\mathrm{C}-5^{\prime}\right), 128.6$ (C-3'), 128.5 (C-5'"'), 128.2 (C-3"'), 126.5 (C-2', 4', 6', 2"', 4"', 6"'), 105.9 (C-10), 102.3 (C-6), 101.2 (C-8), 78.6
$\left(\mathrm{C}-2,\left(\mathrm{CH}_{3}\right)_{3} \mathrm{C}\right), 55.4\left(\mathrm{C}-2^{\prime \prime}\right), 42.2(\mathrm{C}-3), 36.0\left(\mathrm{C}-3^{\prime \prime}\right)$, $27.98\left(\left(\mathrm{CH}_{3}\right)_{3} \mathrm{C}\right)$.

2.2.2(S)-5-Hydroxy-4-oxo-2-phenylchroman-7-yl$N$-(tert-butoxycarbonyl)- $N$-methylglycinate (pb-2) was obtained as yellow powder with a yield of $35.22 \%$; ${ }^{1} \mathrm{H}-\mathrm{NMR}\left(400 \mathrm{MHz}\right.$, DMSO- $d_{6}$, Figure S2-1) $\delta: 11.95$ $(1 \mathrm{H}, \mathrm{s}, \mathrm{OH}), 7.53-7.55\left(2 \mathrm{H}, \mathrm{m}, \mathrm{H}-2^{\prime}, 6^{\prime}\right), 7.40-7.47$ (3H, m, H-3', 4', 5'), 6.34-6.39 (2H, m, H-6, 8), 5.72$5.76(1 \mathrm{H}, \mathrm{m}, \mathrm{H}-2), 4.22-4.23\left(2 \mathrm{H}, \mathrm{m}, \mathrm{H}-2^{\prime \prime}\right), 3.40-3.48$ (1H, m, H-3a), 2.88-2.93 (4H, overlapped, $\left.\mathrm{H}-3 \mathrm{~b}, \mathrm{CH}_{3}-\mathrm{N}\right)$, 1.37-1.41 (9H, overlapped, $\left.\left(\mathrm{CH}_{3}\right)_{3} \mathrm{C}\right) ;{ }^{13} \mathrm{C}-\mathrm{NMR}(100$ MHz, DMSO- $d_{6}$, Figure S2-2) $\delta: 197.7$ (C-4), 168.0 (C-1"), 162.2 (C-5), 157.5 (C-9), 155.3 (C-7), 154.6 (COO), 138.2 (C-1'), 128.6 (C-3', 5'), 126.7 (C-2', 4', 6'), 106.1 (C-10), 102.4 (C-6), 101.3 (C-8), 79.3 (C-2), 78.8 $\left(\left(\mathrm{CH}_{3}\right)_{3} \mathrm{C}\right), 50.6\left(\mathrm{C}-2^{\prime \prime}\right), 42.3(\mathrm{C}-3), 35.4\left(\mathrm{CH}_{3}-\mathrm{N}\right), 27.9$ $\left(\left(\mathrm{CH}_{3}\right)_{3} \mathrm{C}\right)$.

2.2.3 (S)-5-Hydroxy-4-oxo-2-phenylchroman-7-yl (tert-butoxycarbonyl)-alaninate (pb-3) was obtained as yellow powder with a yield of $40.10 \%$; ${ }^{1} \mathrm{H}-\mathrm{NMR}(400$ $\mathrm{MHz}$, DMSO- $d_{6}$, Figure S3-1) $\delta: 11.95(1 \mathrm{H}, \mathrm{s}, \mathrm{OH})$, 7.55-7.58 (2H, m, H-2', 6'), $7.53(1 \mathrm{H}, \mathrm{s}, \mathrm{CONH}), 7.43-$ $7.46\left(3 \mathrm{H}, \mathrm{m}, \mathrm{H}-3^{\prime}, 4^{\prime}, 5^{\prime}\right), 6.32(1 \mathrm{H}, \mathrm{s}, \mathrm{H}-8), 6.30(1 \mathrm{H}, \mathrm{s}$, H-6), 5.75 (1H, s, H-2), 4.17-4.23 (1H, m, H-2"), 3.39$3.47(1 \mathrm{H}, \mathrm{m}, \mathrm{H}-3 \mathrm{a}), 2.88-2.93$ (1H, m, H-3b), 1.36-1.39 
<smiles>CC(C)(C)OC(=O)NC(Cc1ccccc1)C(=O)Oc1cc(O)c2c(c1)O[C@@H](c1ccccc1)CC2=O</smiles>
$\mathrm{pb}-1$<smiles>CC(NC(=O)OC(C)(C)C)C(=O)Oc1cc(O)c2c(c1)O[C@H](c1ccccc1)CC2=O</smiles><smiles>CC(C)(C)OC(=O)NCC(=O)Oc1cc(O)c2c(c1)O[C@H](c1ccccc1)CC2=O</smiles>
$\mathrm{pb}-5$<smiles>CC(C)C[C@H](NC(=O)OC(C)(C)C)C(=O)Oc1cc(O)c2c(c1)O[C@@H](c1ccccc1)CC2=O</smiles><smiles>CN(CC(=O)Oc1cc(O)c2c(c1)O[C@@H](c1ccccc1)CC2=O)C(=O)OC(C)(C)C</smiles>

$\mathrm{pb}-2$<smiles>CC(C)C(NC(=O)OC(C)(C)C)C(=O)Oc1cc(O)c2c(c1)O[C@H](c1ccccc1)CC2=O</smiles><smiles>CC(C)C[C@H](NC(=O)OC(C)(C)C)C(=O)Oc1cc(O)c2c(c1)O[C@@H](c1ccccc1)CC2=O</smiles><smiles>CC(C)(C)OC(=O)N1CCCC1C(=O)Oc1cc(O)c2c(c1)O[C@@H](c1ccccc1)CC2=O</smiles>

Figure I The structures of pinocembrin derivatives I-8.

(12H, overlapped, $\left.\left(\mathrm{CH}_{3}\right)_{3} \mathrm{C}, \mathrm{CH}_{3}-2 "\right) ;{ }^{13} \mathrm{C}-\mathrm{NMR} \quad(100$ MHz, DMSO- $d_{6}$, Figure S3-2) $\delta: 197.5$ (C-4), 171.0 (C-1"), 162.2 (C-5), 162.0 (C-9), 158.0 (C-7), 155.3 (CONH), $138.1\left(\mathrm{C}-1^{\prime}\right), 128.6\left(\mathrm{C}-3^{\prime}\right), 128.5\left(\mathrm{C}-5^{\prime}\right), 126.5$ (C-2', 4', 6'), 105.9 (C-10), 102.3 (C-6), 101.2 (C-8), 78.6 $(\mathrm{C}-2), 78.4 \quad\left(\left(\mathrm{CH}_{3}\right)_{3} \mathrm{C}\right), 54.7 \quad\left(\mathrm{C}-2^{\prime \prime}\right), 42.3(\mathrm{C}-3), 28.0$ $\left(\left(\mathrm{CH}_{3}\right)_{3} \mathrm{C}\right), 16.3\left(\mathrm{CH}_{3}-2^{\prime \prime}\right)$.
2.2.4 (S)-5-Hydroxy-4-oxo-2-phenylchroman-7-yl (tertbutoxycarbonyl)-valinate (pb-4) was obtained as yellow powder with a yield of $40.73 \%$; ${ }^{1} \mathrm{H}-\mathrm{NMR}$ (400 MHz, DMSO- $d_{6}$, Figure S4-1) $\delta: 12.00(1 \mathrm{H}, \mathrm{s}, \mathrm{OH}), 7.55(1 \mathrm{H}, \mathrm{s}, \mathrm{CONH}), 7.39$ $7.53(5 \mathrm{H}, \mathrm{m}, \mathrm{H}-\mathrm{Ph}), 6.31$ (1H, s, H-8), 6.29 (1H, s, H-6), 5.69$5.72(1 \mathrm{H}, \mathrm{m}, \mathrm{H}-2), 4.04-4.08\left(1 \mathrm{H}, \mathrm{m}, \mathrm{H}-2^{\prime \prime}\right), 3.34-3.42$ (1H, m, H-3a),2.88-2.93 (1H, m, H-3b), 2.17-2.24 (1H, m, 


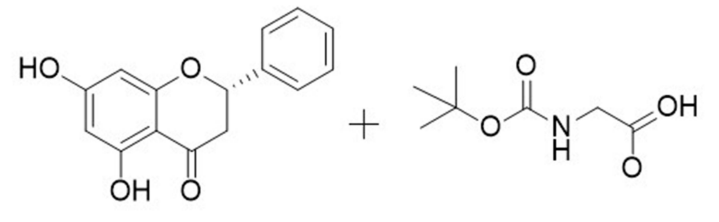

Figure 2 The synthetic route of Boc-Gly-OH.

H-3"), $1.42\left(9 \mathrm{H}, \mathrm{s},\left(\mathrm{CH}_{3}\right)_{3} \mathrm{C}\right), 0.99-1.01$ (6H, overlapped, $\left.\left(\mathrm{CH}_{3}\right)_{2}-3^{\prime \prime}\right) ;{ }^{13} \mathrm{C}-\mathrm{NMR}\left(100 \mathrm{MHz}\right.$, DMSO- $d_{6}$, Figure S4-2) $\delta: 197.4$ (C-4), 169.9 (C-1"), 162.3 (C-5), 162.0 (C-9), 157.8 (C-7), 155.9 (CONH), 138.1 (C-1'), 128.4 (C-3', 5'), 126.4 (C-2', 4', 6'), 105.9 (C-10), 102.3 (C-6), 101.2 (C-8), 78.7 (C-2), $78.4\left(\left(\mathrm{CH}_{3}\right)_{3} \mathrm{C}\right), 59.7\left(\mathrm{C}-2^{\prime \prime}\right), 42.4(\mathrm{C}-3), 29.4\left(\mathrm{C}-3^{\prime \prime}\right)$, $28.0\left(\left(\mathrm{CH}_{3}\right)_{3} \mathrm{C}\right), 18.8\left(\mathrm{C}-4^{\prime \prime}\right), 18.4\left(\mathrm{C}-5^{\prime \prime}\right)$.

2.2.5 (S)-5-hydroxy-4-oxo-2-phenylchroman-7-yl (tertbutoxycarbonyl) glycinate (pb-5) was obtained as yellow powder with a yield of $41.10 \%$; ${ }^{1} \mathrm{H}-\mathrm{NMR}(400 \mathrm{MHz}$, DMSO- $d_{6}$, Figure S5-1) $\delta: 11.94(1 \mathrm{H}, \mathrm{s}, \mathrm{OH}), 7.55(1 \mathrm{H}$, brs, CONH), 7.53 (1H, brs, H-4'), 7.42-7.46 (4H, m, H-1', $\left.2^{\prime}, 5^{\prime}, 6^{\prime}\right), 6.35(1 \mathrm{H}, \mathrm{s}, \mathrm{H}-8), 6.33(1 \mathrm{H}, \mathrm{s}, \mathrm{H}-6), 5.72-5.75$ $(1 \mathrm{H}, \mathrm{m}, \mathrm{H}-2), 3.95(2 \mathrm{H}, \mathrm{d}, J=6 \mathrm{~Hz}), 3.43-3.47(1 \mathrm{H}, \mathrm{m}$, H-3a), 2.88-2.93 (1H, m, H-3b), $1.40\left(9 \mathrm{H}, \mathrm{s},\left(\mathrm{CH}_{3}\right)_{3} \mathrm{C}\right)$; ${ }^{13} \mathrm{C}-\mathrm{NMR}$ (100 MHz, DMSO- $d_{6}$, Figure S5-2) $\delta: 197.5$ (C-4), 168.4 (C-1"), 162.1 (C-5), 162.0 (C-9), 157.7 (C-7), $155.8(\mathrm{CONH}), 138.1\left(\mathrm{C}-1^{\prime}\right), 128.6\left(\mathrm{C}-3^{\prime}\right), 128.5\left(\mathrm{C}-5^{\prime}\right)$, 126.5 (C-2', 4', 6'), 105.9 (C-10), 102.4 (C-6), 101.3 (C-8), $78.6 \quad(\mathrm{C}-2), \quad 78.5 \quad\left(\left(\mathrm{CH}_{3}\right)_{3} \mathrm{C}\right), \quad 42.3 \quad\left(\mathrm{C}-3, \quad 2^{\prime \prime}\right), \quad 28.0$ $\left(\left(\mathrm{CH}_{3}\right)_{3} \mathrm{C}\right)$.

2.2.6 (S)-5-Hydroxy-4-oxo-2-phenylchroman-7-yl (tertbutoxycarbonyl)- $L$-leucinate (pb-6) was obtained as yellow powder with a yield of $41.09 \%$; ${ }^{1} \mathrm{H}-\mathrm{NMR}(400 \mathrm{MHz}$, DMSO- $d_{6}$, Figure S6-1) $\delta: 11.94(1 \mathrm{H}, \mathrm{s}, \mathrm{OH}), 7.55(1 \mathrm{H}, \mathrm{s}$, CONH), 7.53 (2H, brs, H-2', 6'), 7.40-7.46 (3H, m, H-3', 4', $\left.5^{\prime}\right), 6.31(1 \mathrm{H}, \mathrm{s}, \mathrm{H}-8), 6.28(1 \mathrm{H}, \mathrm{s}, \mathrm{H}-6), 5.72-5.75(1 \mathrm{H}, \mathrm{m}$, H-2), 4.08-4.15 (1H, m, H-2"), 3.39-3.47 (1H, m, H-3a), 2.88-2.93 (1H, m, H-3b), 1.58-1.71 (2H, m, H-3"), 1.40 $\left(10 \mathrm{H}, \quad \mathrm{s}, \quad\left(\mathrm{CH}_{3}\right)_{3} \mathrm{C}, \mathrm{C}-4^{\prime \prime}\right), \quad 0.89-0.93 \quad(6 \mathrm{H}$, overlapped, $\left.\left(\mathrm{CH}_{3}\right)_{2}-4^{\prime \prime}\right) ;{ }^{13} \mathrm{C}-\mathrm{NMR}\left(100 \mathrm{MHz}\right.$, DMSO- $d_{6}$, Figure S6-2) $\delta$ : 197.7 (C-4), 171.1 (C-1"), 162.2 (C-5), 162.1 (C-9), 158.0 (C-7), 155.7 (CONH), 138.2 (C-1'), 128.7 (C-3'), 128.6 (C-5'), 126.7 (C-2', 4', 6'), 106.0 (C-10), 102.5 (C-6), 101.4 (C-8), $78.7(\mathrm{C}-2), 78.6\left(\left(\mathrm{CH}_{3}\right)_{3} \mathrm{C}\right), 52.3\left(\mathrm{C}-2^{\prime \prime}\right), 42.3\left(\mathrm{C}-3,3^{\prime}\right.$ '), $28.1\left(\left(\mathrm{CH}_{3}\right)_{3} \mathrm{C}\right), 24.3\left(\mathrm{C}-4^{\prime \prime}\right), 22.8\left(\mathrm{C}-5^{\prime \prime}\right), 21.3\left(\mathrm{C}-6^{\prime \prime}\right)$.

2.2.7 (S)-5-Hydroxy-4-oxo-2-phenylchroman-7-yl (tertbutoxycarbonyl)- $D$-leucinate (pb-7) was obtained as yellow powder with a yield of $42.80 \%$; ${ }^{1} \mathrm{H}-\mathrm{NMR}(400 \mathrm{MHz}$,
DMSO- $d_{6}$, Figure S7-1) $\delta: 11.95(1 \mathrm{H}, \mathrm{s}, \mathrm{OH}), 7.55(1 \mathrm{H}, \mathrm{s}$, CONH), 7.49-7.53 (2H, m, H-2', 6'), 7.40-7.46 (3H, m, H-3', 4', 5'), $6.29(1 \mathrm{H}, \mathrm{s}, \mathrm{H}-8), 6.26(1 \mathrm{H}, \mathrm{s}, \mathrm{H}-6), 5.75(1 \mathrm{H}$, s, H-2), 4.03-4.07 (1H, m, H-2"), 3.40-3.47 (1H, m, H-3a), 2.88-2.92 (1H, m, H-3b), 1.88-1.89 (1H, m, H-3"a), 1.46$1.52\left(1 \mathrm{H}, \mathrm{m}, \mathrm{H}-3^{\prime \prime} \mathrm{b}\right), 1.40\left(9 \mathrm{H}, \mathrm{s},\left(\mathrm{CH}_{3}\right)_{3} \mathrm{C}\right), 1.24-1.31$ (1H, m, H-4"), 0.85-0.95 (6H, m, H-5", 6"); ${ }^{13} \mathrm{C}-\mathrm{NMR}$ $\left(100 \mathrm{MHz}, \mathrm{DMSO}-d_{6}\right.$, Figure S7-2) $\delta: 197.5$ (C-4), 169.9 (C-1"), 162.2 (C-5), 162.1 (C-9), 157.7 (C-7), 155.8 (CONH), 138.1 (C-1'), 128.6 (C-3'), 128.5 (C-5'), 126.5 (C-2', 4', 6'), 105.9 (C-10), 102.2 (C-6), 101.2 (C-8), 78.6 $(\mathrm{C}-2), 78.5\left(\left(\mathrm{CH}_{3}\right)_{3} \mathrm{C}\right), 58.6\left(\mathrm{C}-2^{\prime \prime}\right), 42.2(\mathrm{C}-3), 35.6\left(\mathrm{C}-3^{\prime \prime}\right)$, $28.0\left(\left(\mathrm{CH}_{3}\right)_{3} \mathrm{C}\right), 25.0\left(\mathrm{C}-4^{\prime \prime}\right), 15.3\left(\mathrm{C}-5^{\prime \prime}\right), 10.9\left(\mathrm{C}-6^{\prime \prime}\right)$.

2.2 .8 1-(tert-Butyl) 2-((S)-5-hydroxy-4-oxo-2-phenylchroman-7-yl) pyrrolidine-1,2-dicarboxylate (pb-8) was obtained as yellow powder with a yield of $40.77 \%$; ${ }^{1} \mathrm{H}-\mathrm{NMR}$ (400 MHz, DMSO- $d_{6}$, Figure S8-1) $\delta: 11.95$ $(1 \mathrm{H}, \mathrm{s}, \mathrm{OH}), 7.53(2 \mathrm{H}$, brs, H-2', 6') $7.41-7.44(3 \mathrm{H}, \mathrm{m}$, H-3', 4', 5'), $6.36(1 \mathrm{H}, \mathrm{s}, \mathrm{H}-8), 6.32(1 \mathrm{H}, \mathrm{s}, \mathrm{H}-6), 5.75(1 \mathrm{H}$, brs, H-2), 4.37-4.42 (1H, m, H-2"), 3.39-3.42 (2H, m, H-5"), 3.34-3.37 (1H, m, H-3a), 2.89-2.93 (1H, m, H-3b), 1.85-1.96 (4H, m, H-3", 4"), 1.37-1.41 (9H, overlapped, $\left.\left(\mathrm{CH}_{3}\right)_{3} \mathrm{C}\right) ;{ }^{13} \mathrm{C}-\mathrm{NMR}\left(100 \mathrm{MHz}\right.$, DMSO- $d_{6}$, Figure S8-2) $\delta$ : 197.5 (C-4), 170.4 (C-1"), 163.4 (C-5), 162.6 (C-9), 157.6 (C-7), 155.8 (COO), 137.9 (C-1'), $128.5\left(\mathrm{C}-3^{\prime}, 5^{\prime}\right)$, 126.5 (C-4'), 126.3 (C-2', 6'), 106.0 (C-10), 102.2 (C-6), $101.1(\mathrm{C}-8), 79.1(\mathrm{C}-2), 78.7\left(\left(\mathrm{CH}_{3}\right)_{3} \mathrm{C}\right), 58.6\left(\mathrm{C}-2^{\prime \prime}\right), 54.7$ $\left(\mathrm{C}-5^{\prime \prime}\right), 30.1\left(\mathrm{C}-3^{\prime \prime}\right), 27.9\left(\left(\mathrm{CH}_{3}\right)_{3} \mathrm{C}\right), 24.0\left(\mathrm{C}-4^{\prime \prime}\right)$.

\section{C. elegans Thermal Stress Resistance Assay}

Age-synchronized wild-type L4 larvae were transferred to NGM plate treated with or without $200 \mu \mathrm{M}$ drug and incubated at $20^{\circ} \mathrm{C}$. They were transferred onto a new NGM plate every day. On day 5, they were incubated at $37^{\circ} \mathrm{C}$ for $3 \mathrm{~h}$. Then, the worms were recorded as dead if they failed to respond to a gentle touch with a platinum wire pick every $0.5 \mathrm{~h}$ until all the nematodes died. The experiment was repeated three times independently. 


\section{C. elegans Oxidative Stress Resistance Assay}

Age-synchronized wild-type L4 larvae were transferred to an NGM plate treated with or without $200 \mu \mathrm{M}$ drug and incubated at $20^{\circ} \mathrm{C}$. They were transferred onto a new NGM plate every day. On day 5 , they were transferred onto new plate containing hydrogen peroxide (each $1 \mathrm{~mL}$ medium contained $4 \mu \mathrm{L}$ hydrogen peroxide solution). Then, the worms were considered dead if they failed to respond to a gentle touch with a platinum wire pick every $0.5 \mathrm{~h}$ until all the nematodes died. The experiment was repeated three times independently.

\section{Determination of Body Length}

Age-synchronized wild-type L4 larvae were transferred to a new plate treated with or without $200 \mu \mathrm{M}$ drug and incubated at $20^{\circ} \mathrm{C}$. On day 2, the nematodes in each experimental group were placed in the anesthetic located in the center of the agarose pad on a microscope slide. Images of individual nematodes were taken with a microscope and analyzed to determine the length of each animal using NIS-Elements software.

\section{Determination of the Lipofuscin Level in C. elegans}

Age-synchronized wild-type L4 larvae were transferred to a new plate treated with or without $200 \mu \mathrm{M}$ drug and incubated at $20^{\circ} \mathrm{C}$. They were transferred onto a new plate every day. On day 9 , the nematodes in each experimental group were placed in the anesthetic located in the center of the agarose pad on a microscope slide. Images of individual nematodes were taken with a fluorescence microscope and analyzed to calculate the fluorescence intensity in nematodes using ImageJ software.

\section{Pharyngeal Pumping Assay}

To investigate phenotypic changes associated with aging, the pharyngeal pumping rate was also measured. Young adults take an average of 250-300 puffs per minute, which decreases as they age. Age-synchronized wild-type L4 larvae were transferred to NGM plate treated with or without $200 \mu \mathrm{M}$ drug and incubated at $20^{\circ} \mathrm{C}$. They were transferred onto a new plate every day. The pharyngeal pumping rate was counted for $20 \mathrm{~s}$ on day 3 , day 5 and day 7. Each group included 10 worms.

\section{Determination of Lipofuscin}

\section{Accumulation}

Age-synchronized wild-type L4 larvae were transferred to a NGM plate treated with pinocembrin amino acids derivatives and incubated at $20^{\circ} \mathrm{C}$. They were transferred onto a new NGM plate every day. On day 9, the nematodes in each experimental group were placed in the anesthetic located in the center of the agarose pad on a microscope slide. Images of individual nematodes were taken with a fluorescence microscope and analyzed to calculate the fluorescence intensity of the nematodes using ImageJ software.

\section{Determination of Intracellular ROS}

DCFH-DA fluorescent probes are able to cross the cytomembrane. After entering the cell, DCFH-DA can be hydrolyzed by intracellular esterase to form DCF, which can not penetrate the cell membrane; thus, the probe is easily loaded into the cell. Reactive oxygen species in cells can oxidize nonfluorescent DCFH to produce fluorescent DCF. The level of reactive oxygen species in cells is reflected by detecting the fluorescence of $\mathrm{DCF}^{29,30}$

Age-synchronized wild-type L4 larvae were transferred to an NGM plate treated with or without $200 \mu \mathrm{M}$ drug and incubated at $20^{\circ} \mathrm{C}$. They were transferred onto a new NGM plate every day. On day 5, they were transferred onto a new NGM containing hydrogen peroxide and stimulated for $2 \mathrm{~h}$. Next, the nematodes were washed with M9 buffer and transferred a $0.2 \mathrm{~mL}$ centrifuge tube. Then the nematodes were treated with $20 \mu \mathrm{M}$ DCFH-DA in the dark for $2 \mathrm{~h}$ at $20{ }^{\circ} \mathrm{C}$. The worms were washed with $\mathrm{M} 9$ buffer to remove the dye and then placed in the anesthetic located in the center of the agarose pad on a microscope slide. Images of individual nematodes were taken with a fluorescence inverted microscope (excitation: $485 \mathrm{~nm}$; emission: $530 \mathrm{~nm}$ ) and analyzed to calculate the fluorescence intensity of the nematodes using ImageJ software.

\section{SOD-3 Expression in Transgenic Strains of $C$. elegans}

Transgenic C. elegans CF1553 expressing the sod-3::GFP reporter were generated, and the GFP fluorescence intensity of each group of nematodes could be observed by an inverted fluorescence inverted microscope to detect the expression of SOD-3 in nematodes.

Age-synchronized wild-type L4 larvae were transferred to a new NGM plate treated with or without $200 \mu \mathrm{M}$ drug and incubated at $20^{\circ} \mathrm{C}$ for $3 \mathrm{~d}$. And then 
they were transferred onto a new NGM containing hydrogen peroxide to be stimulated for $2 \mathrm{~h}$. Images of individual nematodes were taken with a fluorescence inverted microscope and analyzed to calculate the fluorescence intensity of the nematodes using ImageJ software.

\section{DAF-I 6 Nuclear Translocation Assay}

The transgenic C. elegans TJ356 expressing DAF-16::GFP reporter was used to detect the nuclear localization of DAF-16. DAF-16 protein is related to the formation of the nematode dauer stage, longevity and stress resistance, and it is inhibited by the insulin signaling pathway. To investigate the effect of compound pb-3 on DAF-16, the eggs of age-synchronized TJ356 nematodes were treated with or without $200 \mu \mathrm{M}$ drug. Three days later, the nematodes developed into young adults. Images of individual nematodes were taken with an inverted fluorescence microscope (excitation: $488 \mathrm{~nm}$; emission: $500-530 \mathrm{~nm}$ ), and the fluorescence was analyzed to calculate nuclear localization.

\section{Effect of Pb-3 on the Survival of Hsp 16.2, Daf-2, and Age-I Mutants}

Age-synchronized wild-type L4 larvae were transferred to an NGM plate treated with or without $200 \mu \mathrm{M}$ drug and incubated at $20^{\circ} \mathrm{C}$. They were transferred onto new NGM plate every day. On day 5 , they were transferred onto new plate containing hydrogen peroxide (each $1 \mathrm{~mL}$ medium contained $4 \mu \mathrm{L}$ hydrogen peroxide solution). Then, the worms were considered dead if they failed to respond to a gentle touch with a platinum wire pick every $0.5 \mathrm{~h}$ until all the nematodes died. The experiment was repeated three times independently.

\section{Statistical Analysis}

All graphs were generated with GraphPad Prism (GraphPad Software Inc.). The data from the stress resistance assays were plotted using Kaplan-Meier analysis, and statistical significance was analyzed by the Log rank test. The significant of differences between the control and treated groups were analyzed by one-way analysis of variance (ANOVA). All $P$-values less than 0.05 were considered statistically significant. All the values expressed as percentages (\%) were normalized to the control values, which were set to $100 \%$.

\section{Results and Discussion} Effect of Pinocembrin Amino Acid Derivatives on the Lifespan of Wild-Type C. elegans Under Thermal Stress

During the aging process, the ability of organisms to respond to external stimuli progressively declines. Thermotolerance ability is an important criteria for evaluating the aging process of organisms. ${ }^{31}$ As shown in Figure 3, pinocembrin derivatives were screened for their protective effects at a concentration of $200 \mu \mathrm{M}$. Compared with the control group, the survival curves of the pb-2-, pb-3-, pb-4-, and pb-5-treated groups showed a significant shift to the right $(P<0.001)$. In addition, the median survival time of these four groups (all 3.5 hours) was higher than that of the control group ( 2.5 hours) average length, while the median survival time of the pinocembrin group was 3 hours.

\section{Effect of Pinocembrin Amino Acid Derivatives on the Lifespan of Wild-Type C. elegans Under Oxidative Stress}

To explore the protective effects against oxidative stress, we analyzed derivatives-treated worms undergoing $\mathrm{H}_{2} \mathrm{O}_{2}$ oxidative stress. As shown in Figure 4, pinocembrin derivatives were further screened for their protective effects at a concentration of $200 \mathrm{mM}$. Pb-3 exhibited significant activities $(P<0.001)$. The median survival time of $\mathbf{p b - 3}$ group was 4 hours, and the median survival time of the pinocembrin group was 3 hours, which was longer than the control group (2.5 hours).

\section{Effect of Pinocembrin Amino Acid Derivatives on Body Length}

Changes in body length reflect the growth rate and physiological state of $C$. elegans. In this study, body length was measured to examine the development rate of the worms. The analyses of body length revealed no is found in the mean body length in worms treated with $200 \mu \mathrm{M}$ of amino acid derivatives compared with the control worms $(P>0.05$, Figure 5).

\section{Effect of Pinocembrin Amino Acid Derivatives on Lipofuscin Levels in C. elegans}

Generally, the content of lipofuscin in nematodes gradually increases with age. Lipofuscin is widely regarded as a biomarker of aging that cannot be excreted by exocytosis 


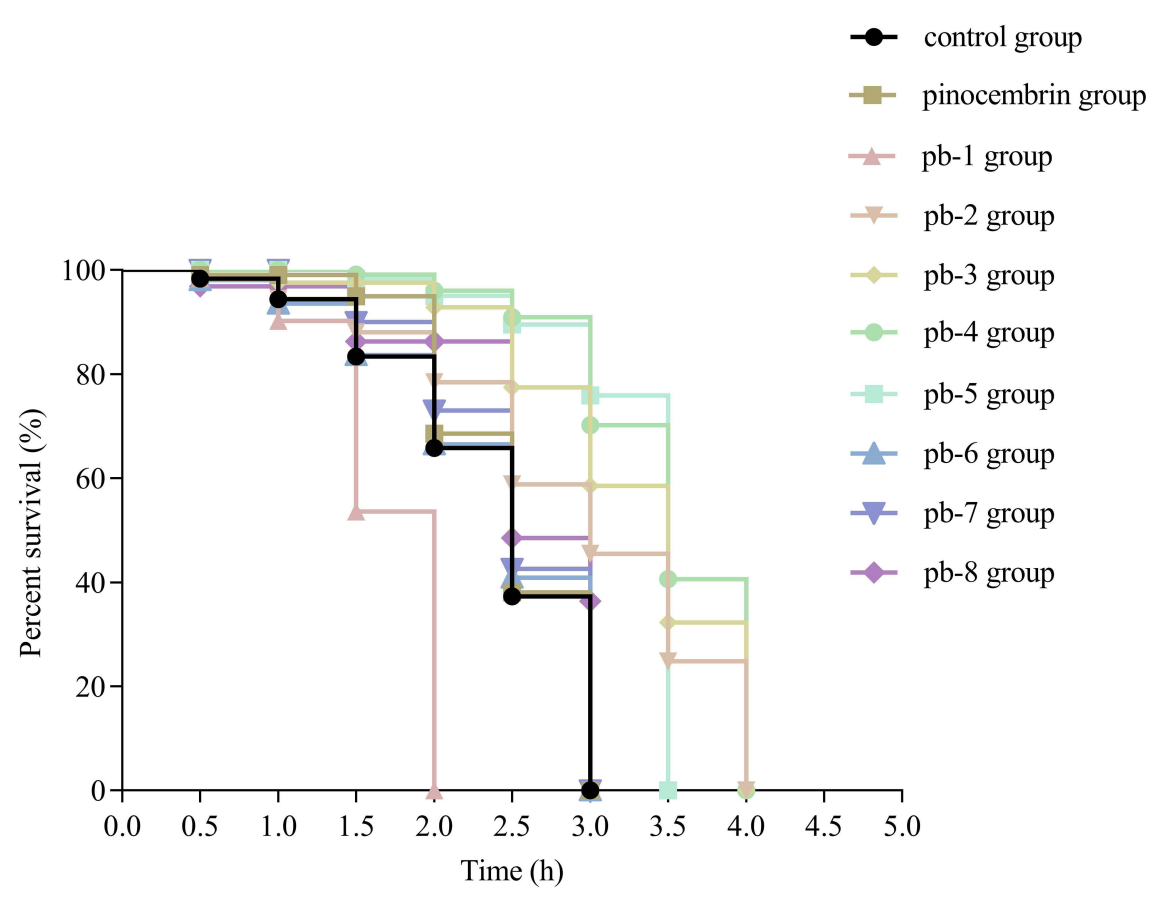

Figure 3 Effect of pinocembrin amino acid derivatives on the wild-type $C$. elegans lifespan under thermal stress conditions.

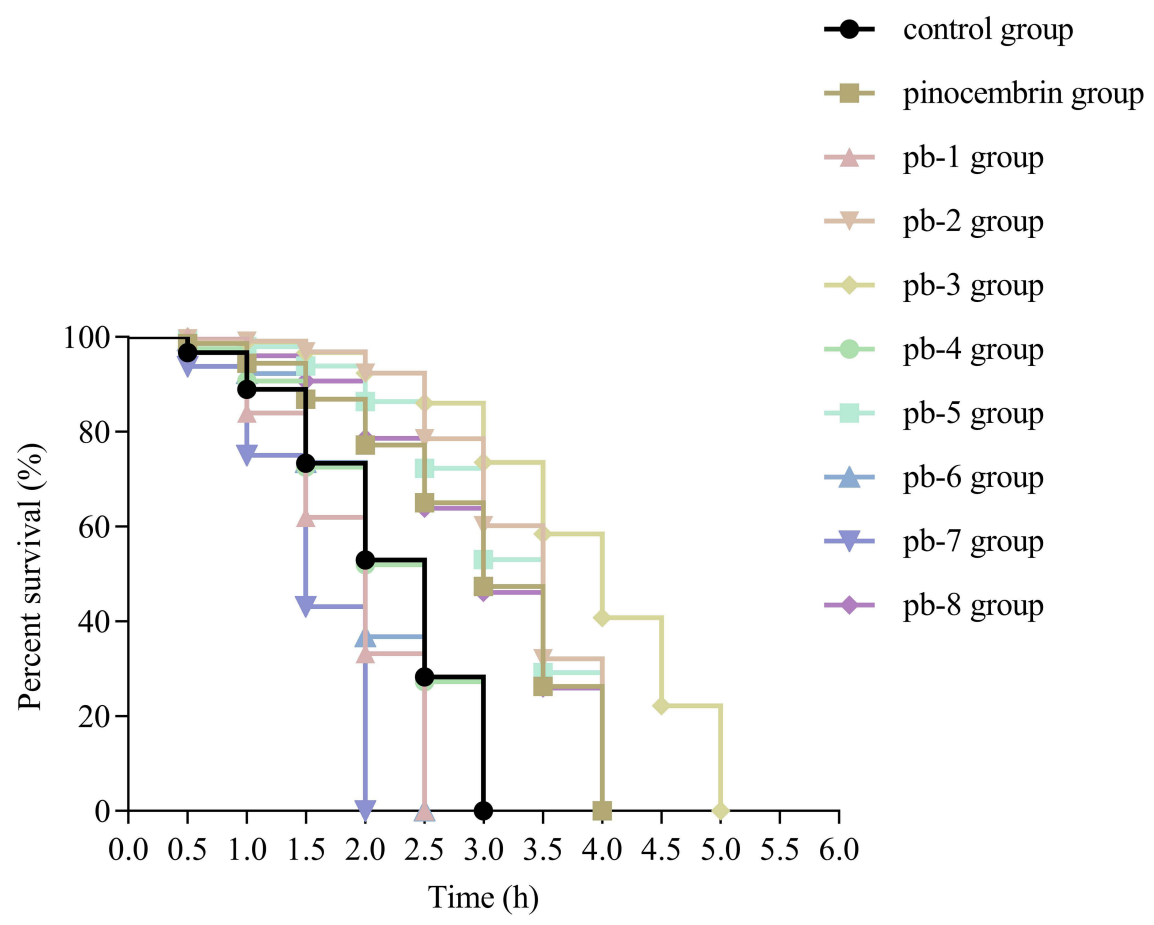

Figure 4 Effect of pinocembrin amino acid derivatives on the lifespan of wild-type $C$. elegans lifespan under oxidative stress conditions.

and can accumulate over time in cells over time. ${ }^{32,33}$ Excessive lipofuscin precipitation would cause damage to the body of nematodes, and eventually accelerate the aging of nematodes. ${ }^{34,35}$ Under an inverted fluorescence microscope, the blue autofluorescence of lipofuscin was observed in the nematodes (Figure 6A-J). Through the calculation of fluorescence density, we found that $\mathbf{p b}-\mathbf{2}$ and $\mathbf{p b}-\mathbf{3}$ could reduce the accumulation of lipofuscin (Figure 6K), which proved the effects of these derivatives on delaying the aging of nematodes. 


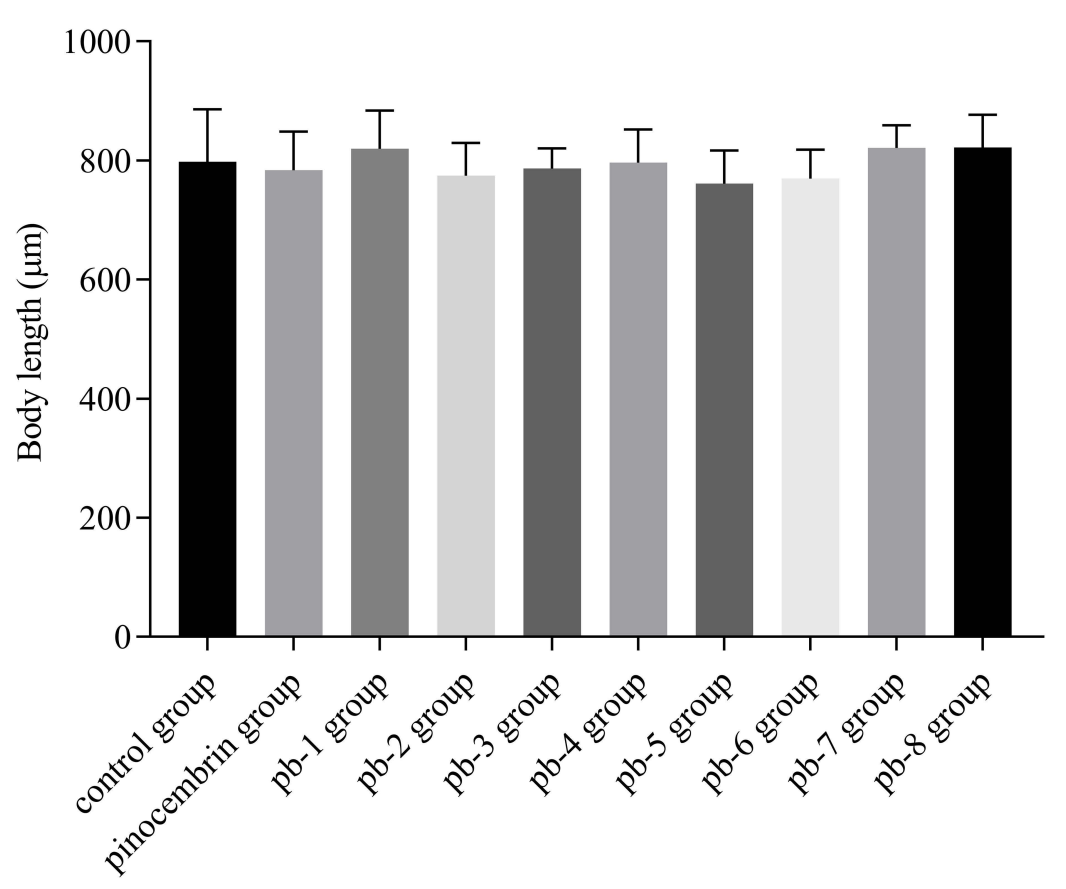

Figure 5 Effect of pinocembrin amino acid derivatives on body length in wild-type $C$. elegans.

In summary, pb-3 was the most potent compound and was further screened for its protective effects at three concentrations. We measured the autofluorescence level of lipofuscin (Figure 7A-D), and the results revealed that the pb-3-treated worms exhibited significantly attenuated fluorescence intensity from intestinal lipofuscin compared with the control groups $(35 \%$ decrease; $P<0.0001$, Figure 7E).

\section{Pharyngeal Pumping}

The rate of pharyngeal pumping was measured to determine the feeding behavior of worms, as the healthy life span of an organism is dependent on its feeding behavior. ${ }^{36}$ The slow feeding rate corresponds to a DR (dietary restriction) induced lifespan promoting effect in C.elegans. ${ }^{37}$ To eliminate the possibility that the detected protective effects (eg, an increase in life span during oxidative stress or antioxidative effects) may be due to caloric restriction, the number of pharyngeal pump times of the nematodes within 20s were measured on the $2 \mathrm{nd}, 4$ th and 6 th days. The experiment data showed that the pharyngeal pumping frequency of the nematodes in the control group gradually decreased with increasing age. This result might be due to the degradation of muscles and the nervous system caused by aging. As shown in Figure 8, compared with the control group, the pharyngeal pump frequency of the experimental group was slightly increased, but there was no significant difference
( $P>0.05)$, indicating that $\mathbf{p b - 3}$ had no effect on the intake of nematodes. Furthermore, the mechanism by which pb-3 prolongs the lifespan of nematodes was not achieved by DR.

\section{$\mathrm{Pb}-3$ Reduced Intracellular ROS Accumulation in $C$. elegans}

The results mentioned above indicated that $\mathbf{p b - 3}$ could significantly improve the stress resistance of nematodes at the organismal level. Therefore, the levels of ROS were investigated to determine the mechanism by which pb-3 protects oxidative damage. The fluorescence pictures of control group, oxidatively stimulated nematodes under non-administered conditions and oxidatively stimulated nematodes under administered conditions are shown in Figure 9A-C. The ROS content is directly associated with oxidative stress. ${ }^{38}$ As shown in Figure 9D, pb-3 treatment significantly downregulated regulated the level of ROS in nematodes compared with the $\mathrm{H}_{2} \mathrm{O}_{2}$ treatment $(p<0.001)$.

\section{$\mathrm{Pb}-3$ Enhanced the Expression the Stress-Inducible Genes Sod-3 Gene in \\ C. elegans}

As shown in Figure 10A and B, after nematodes were exposed to $\mathbf{p b}-3$ for $72 \mathrm{~h}$, green fluorescence only appeared 


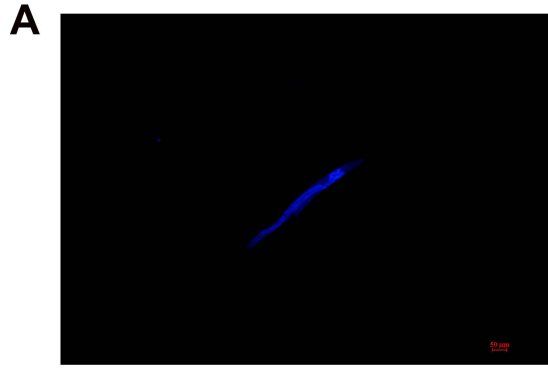

D

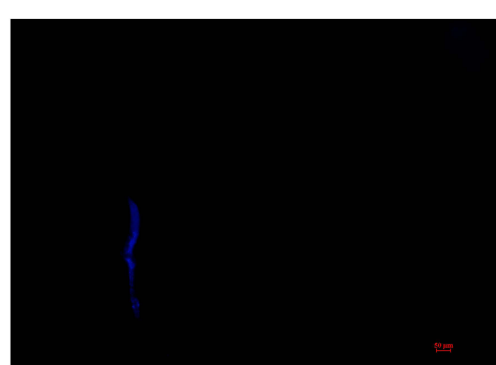

G
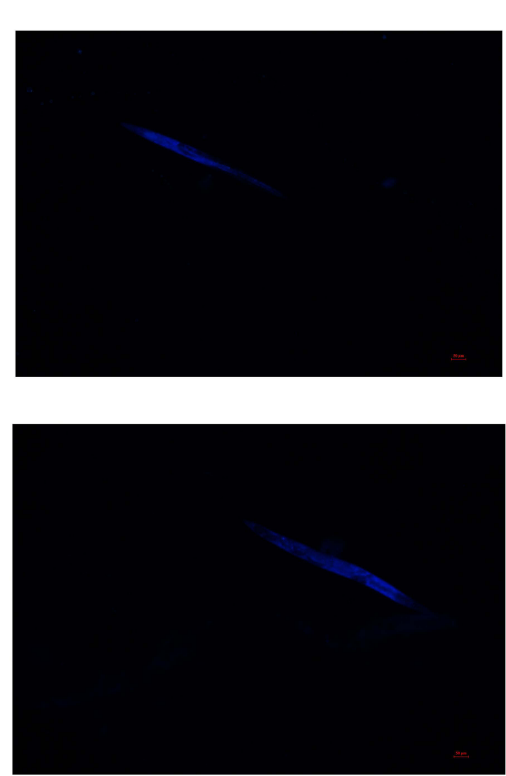

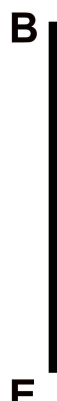

E
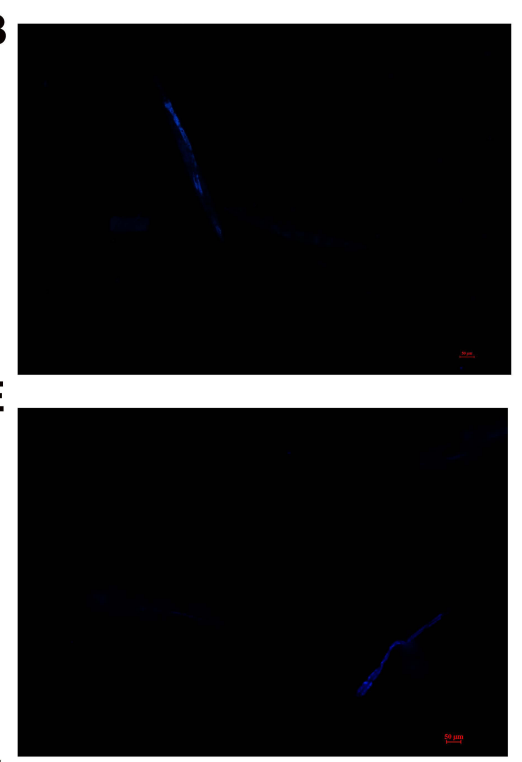

H

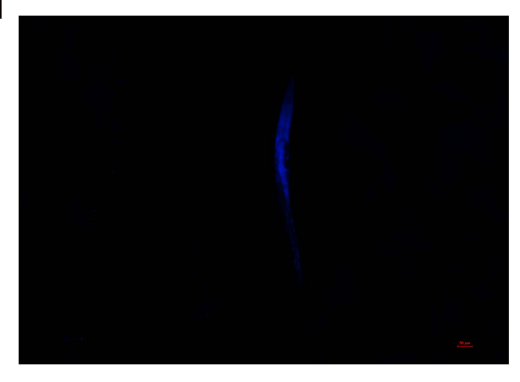

J

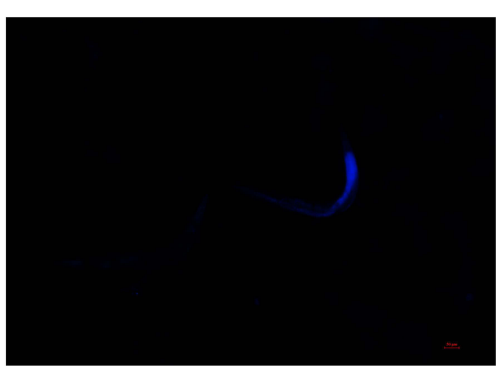

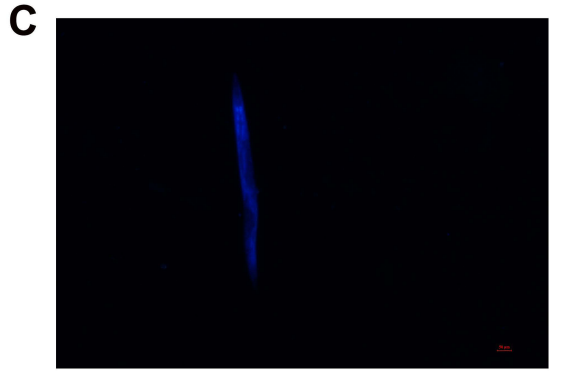

$F$

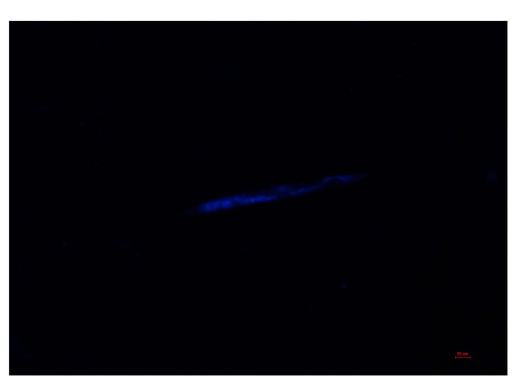

K

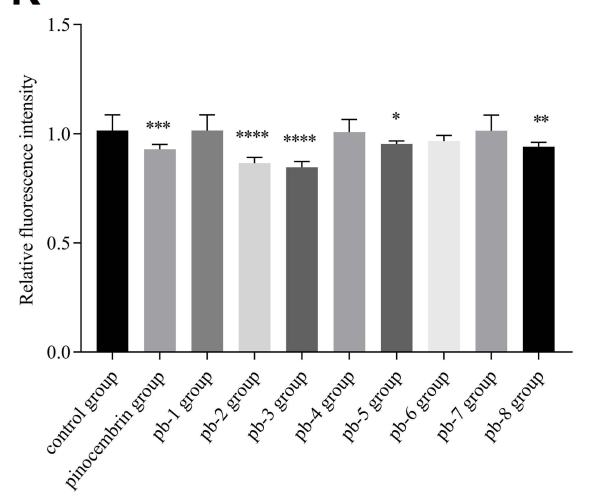

Figure 6 Effect of pinocembrin derivatives on aging pigment lipofuscin levels of wild-type $C$. elegans. ((A) Control group; (B) pinocembrin group; (C) pb-I group; (D) pb-2 group; (E) pb-3 group; (F) pb-4 group; (G) pb-5 group; (H) pb-6 group; (I) pb-7 group; (J) pb-9 group) Representative pictures of lipofuscin accumulation in nematodes. (K) The relative fluorescence intensity of lipofuscin accumulation. Bars with different letters indicate that the values were significantly different $(* p<0.05$, $* * p<0.01$, $*_{* *}<0.001$, and $* * * * p<0.0001$ ).

in the heads and tails of the nematodes. Statistical analysis was carried out on the level of fluorescence, as shown in Figure $10 \mathrm{C}$, there was no significant difference have been found between the experimental group and control group in terms of total fluorescence yield $(p>0.05)$, which illustrated that pb-3 cannot promote sod-3 gene expression under normal living conditions.

Therefore, we studied the effect of $\mathbf{p b - 3}$ on the expression of the sod- 3 gene under oxidative stress conditions. After being exposed to $\mathrm{H}_{2} \mathrm{O}_{2}$ for an additional $2 \mathrm{~h}$, the nematodes were almost full of green fluorescence as observed under a fluorescence microscope (Figure 11A and $\mathrm{B})$. Pb-3 significantly increased the total amount of green fluorescent protein compared with the control ( $p<0.001$, Figure 11C), which indicates that $\mathbf{p b - 3}$ can increase the expression of the sod-3 gene and enhance the antioxidative stress ability under oxidative stress. This finding further explains the increased survival rate and decreased ROS content under $\mathrm{H}_{2} \mathrm{O}_{2}$ oxidative stress in our previous study. The sod-3 gene, which is 

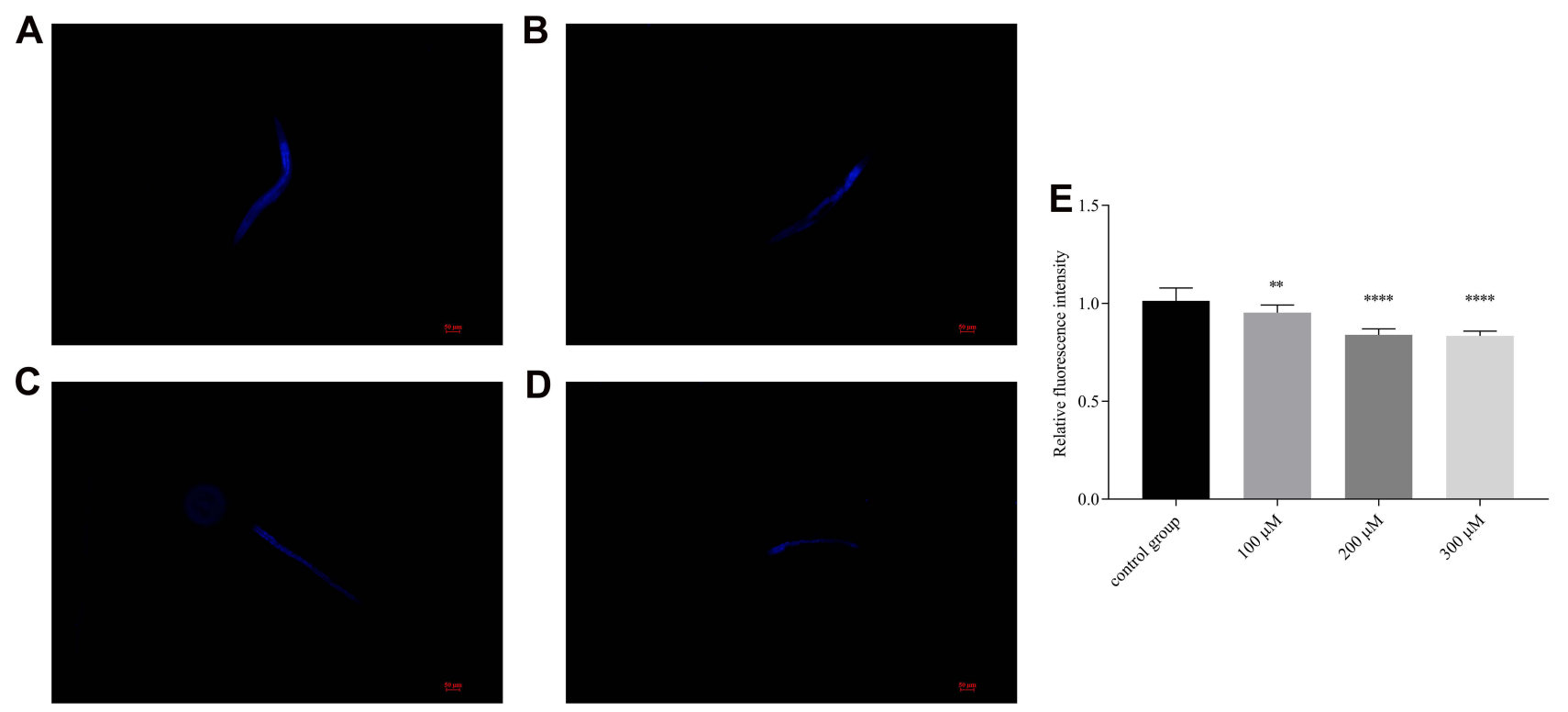

Figure 7 Effect of pb-3 on aging-related pigment lipofuscin levels of wild-type $C$. elegans. ((A) control group; (B) $100 \mu M$ group; (C) $200 \mu M$ group; (D) $300 \mu M$ group) Representative images of lipofuscin accumulation in nematodes. (E) The relative fluorescence intensity of lipofuscin accumulation. Bars with different letters indicate that the values were significantly different $(* p<0.05, * * p<0.01$, **** $<0.001$, and $* * * * p<0.0001)$.

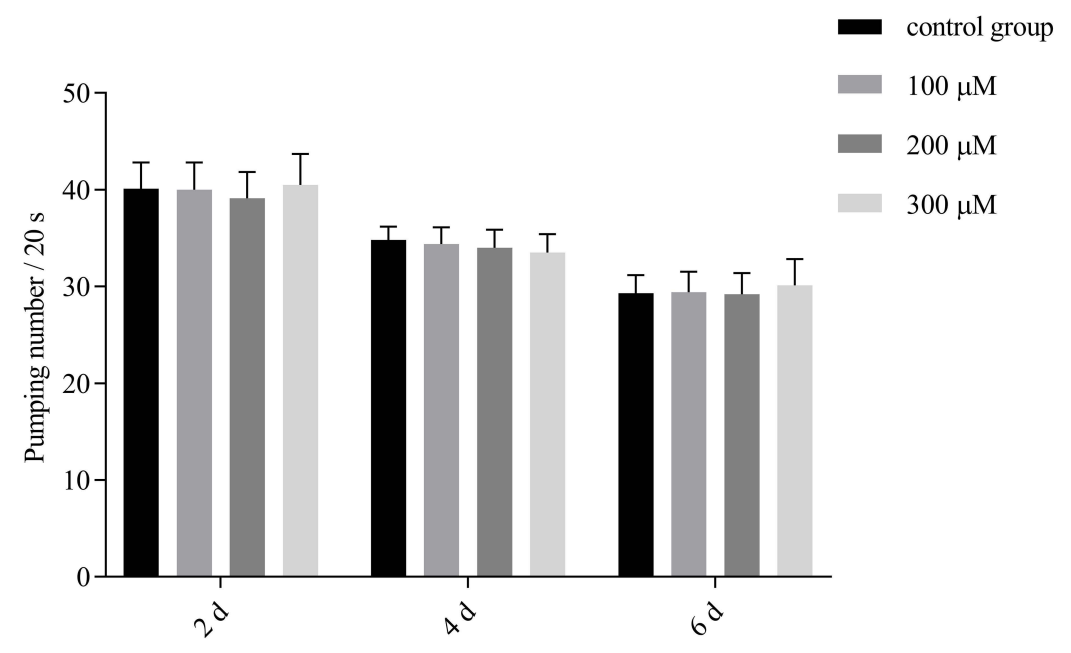

Figure 8 Impact of pb-3 on the pharyngeal pumping rate of wild-type $C$. elegans.

a downstream factor of the $d a f-16$ gene, is regulated by the $\mathrm{d} a f-2 / d a f-16$ gene and is related to lifespan. ${ }^{39}$

\section{Effect of Pb-3 on DAF-16 Localization in the TJ356 C. elegans Strain}

To verify that the expression of the daf-16 gene was increased, we conducted an assay with the TJ356 strain, which showed the nuclear localization of daf-16 during stress. To confirm the involvement of the daf-16 gene, we used a TJ356 C. elegans strain in which DAF-16 was tagged with GFP.
Under normal growth conditions, DAF-16 was mainly retained in the cytoplasm, and pb-3 did not promote the nuclear localization of DAF-16 but distinctly promoted nuclear localization under the oxidative stress induced by $\mathrm{H}_{2} \mathrm{O}_{2}$, as shown in Figure 12A-D. Based on counting fluorescence points, $\mathbf{p b - 3}$ led to the translocation of DAF-16 from the cytoplasm to the nucleus (Figure 12E). The localization of DAF-16 in the nucleus is essential for the activation of the transcription of various genes that mediate stress resistance. Thus, our studies indicate that $\mathbf{p b - 3}$ activates the 


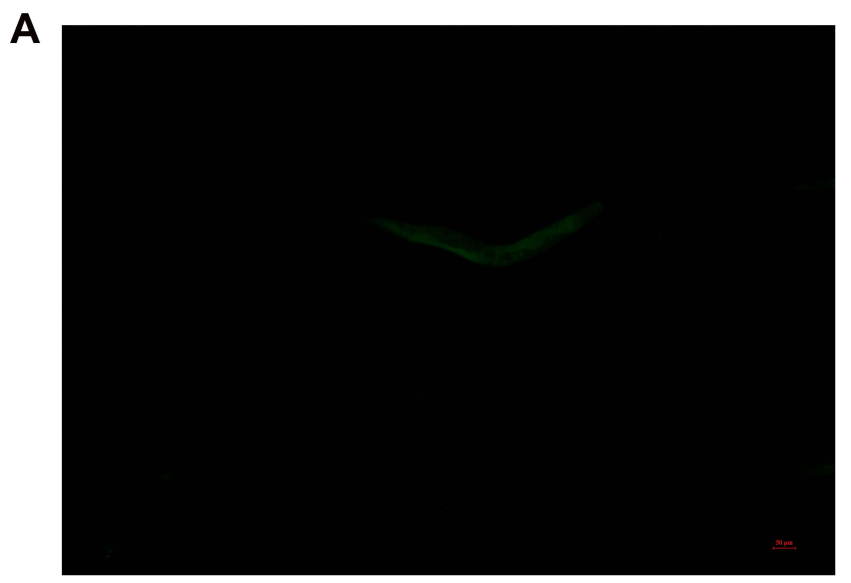

C

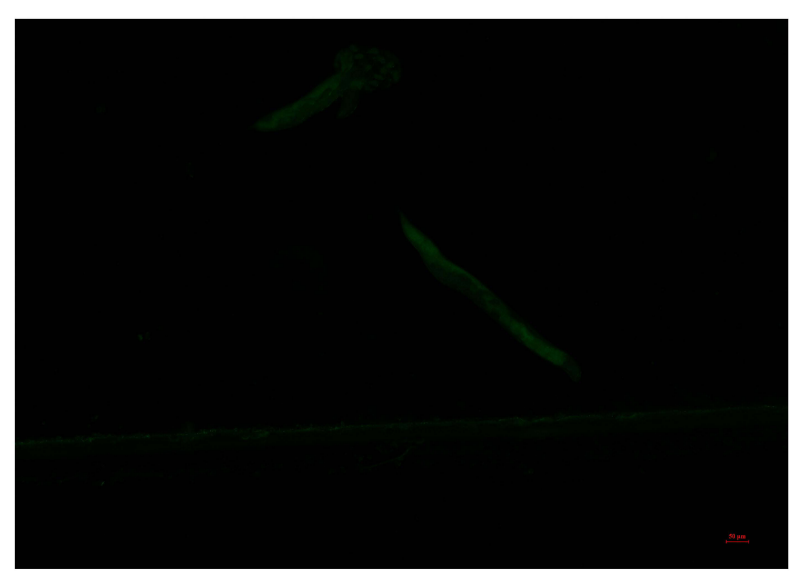

B

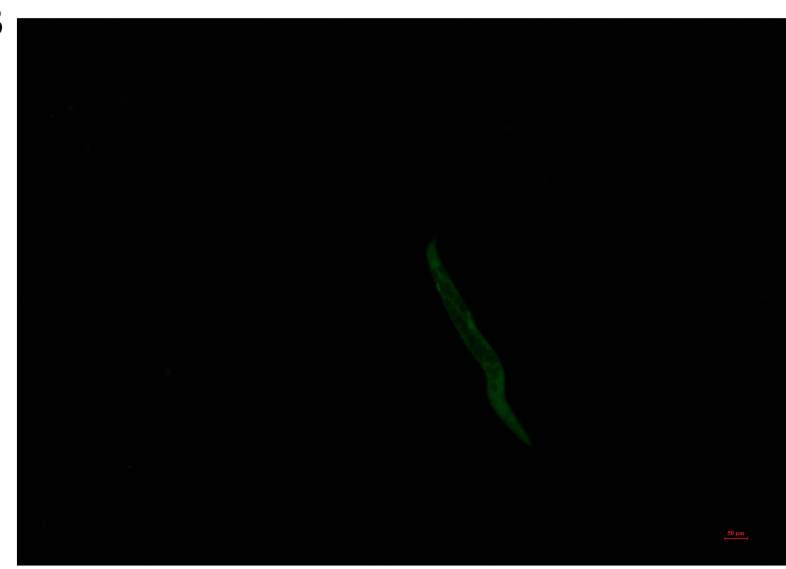

D

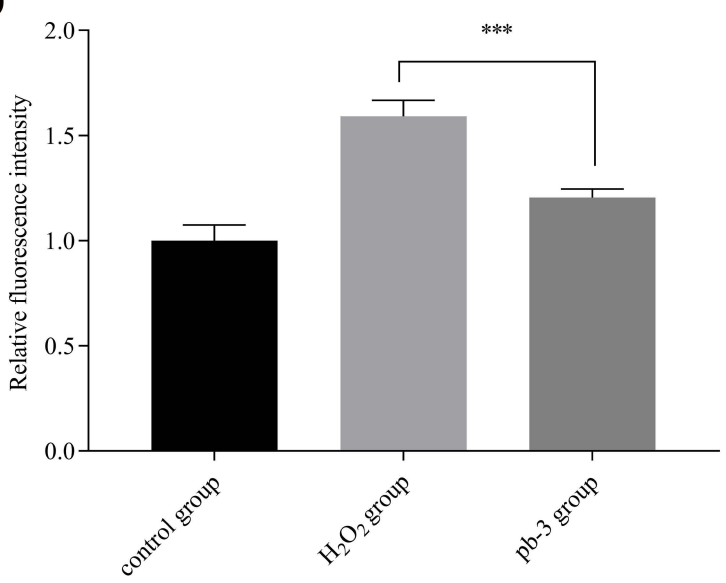

Figure 9 ((A) control group; (B) $\mathrm{H}_{2} \mathrm{O}_{2}$ group; (C) pb-3 group) fluorescence pictures of each group of wild-type $C$. elegans. (D) Effect of pb-3 on intracellular ROS accumulation in wild-type $C$. elegans $(* * * p<0.00$ I).

DAF-16 transcription factor through the insulin/IGF-1 signaling pathway.

To confirm further whether pb-3-mediated oxidative stress resistance requires $d a f-16$, we investigated the beneficial effect of pb-3 on a daf-16 null mutant (DR26). The results showed that pb-3 was unable to increase the survival rate of these worms. Pb-3 protected $C$. elegans from stress conditions in a DAF-16dependent manner (Figure 13A).

\section{Effect of Pb-3 on the Survival of Loss-of- Function Mutant Strains}

DAF-16 plays an important role in regulating stress resistance through its downstream target genes such as sod-3 and $h$ sp 16.2. ${ }^{40}$ We evaluated the antiaging effect of pb-3 under various culture conditions. Under heat stress, pb-3 could significantly improve the survival of N2 worms. This result occurs might due to the effect of pb-3 on the upregulated expression of the heat shock protein $h s p-16.2$, which could improve stress resistance and serve as a stress-sensitive reporter to predict longevity in C. elegans. ${ }^{41,42}$ As shown in Figure 13B, pb-3 was unable to increase the survival rate of worms. $\mathbf{P b} \mathbf{b}$ protected C. elegans from stress conditions in a $h s p$ 16.2-dependent manner. Daf-2 can regulate the nuclear translocation of DAF-16. ${ }^{43,44}$ DAF-2 is a C. elegans homolog for the mammalian IGF-1 receptor and is the only IGF-1/insulin signaling receptor present in C. elegans, whereas AGE-1 is a homolog for the mammalian PI3K catalytic subunit. ${ }^{45}$ Mutations in both age1 and $d a f-2$ have been reported to result in an increased life span. $^{46,47} \mathbf{P b - 3}$ treatment did not significantly enhance the lifespan of either the daf-2(e1370) or age1(hx546) mutant strains (Figure 13C and D). The results thus show that the effects of pb-3 treatment are DAF-2-, AGE-1-, and DAF-16-dependent. 


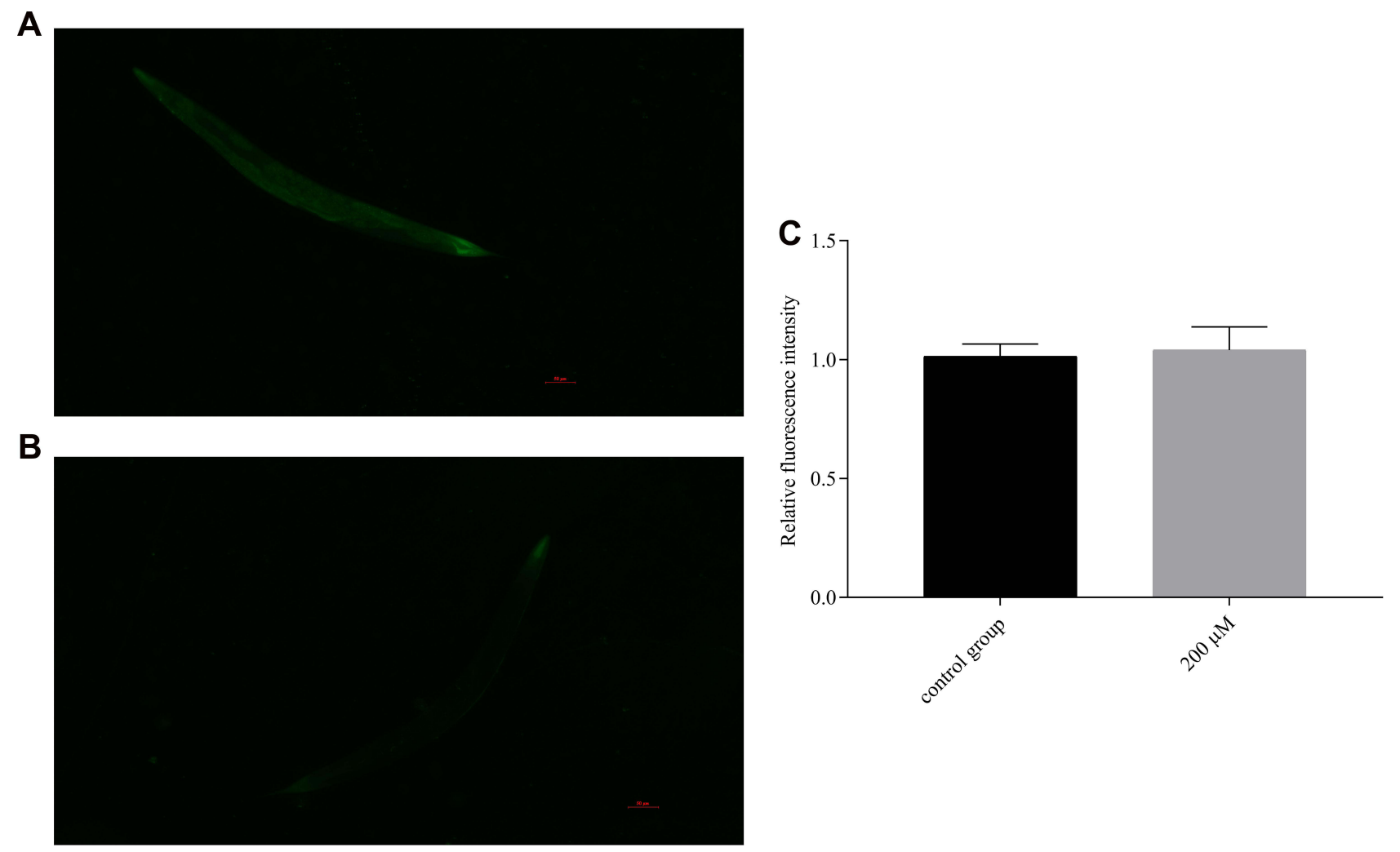

Figure 10 Fluorescence pictures of each group of CFI553C. elegans ((A) control group; (B) $200 \mu \mathrm{M}$ group). (C) Effect of pb-3 on the fluorescent expression of CFI553C. elegans (compared with the control group, $p>0.05$ ).

\section{Conclusion}

In this study, 8 novel pinocembrin derivatives were designed and synthesized with different amino acids. All of these derivatives were characterized by ${ }^{1} \mathrm{H}-\mathrm{NMR}$ and ${ }^{13} \mathrm{C}$-NMR. Their antiaging effects were demonstrated by using a $C$. elegans model system for the first time. Among these the derivatives, pb-3 has been found to exhibit the best effects, depending on the results of survival curve under stress conditions and the low levels of lipofuscin in C. elegans.

This study demonstrates that $\mathbf{p b - 3}$ could promote the lifespan and health span of $C$. elegans, reduce accumulation of lipofuscin, and improve stress resistance (including thermal stress and oxidative stress). Compare with pinocembrin, pb-3 was obtained by introducing alanine amino acid and presents better antiaging activity. The study also revealed that pb-3 could increase the SOD activities and reduce the ROS levels in C. elegans, which are the reasons underlying the improved stress resistance, especially oxidative stress resistance. The increased lifespan in C. elegans under treatment with pb-3 is dependent on the DAF-16 pathway. DAF-16 translocation to the nucleus can further trigger the transcriptional activation of genes, including sod-3 and hsp-16.2. Furthermore, the study of gene indicated that the IIS pathway may be involved in the lifespan extension which mediated by pb-3. We assume that the mode of action of $\mathbf{p b - 3}$ is linked to inhibition of proteins in the insulin/IGF-1 signaling pathway as well as to the inherent antioxidant properties.

In summary, pb-3 exerts oxidative stress resistance effects via the DAF-16/FOXO signaling pathways. In the future, it is worth to discuss the difference between the antiaging effects of $\mathbf{p b - 3}$ and other mature antiaging compounds. In addition, further studies are needed to elucidate the underlying mechanisms by which pb-3 extends the lifespan of $C$. elegans, and in vivo assays with more complex model organisms are also needed. 


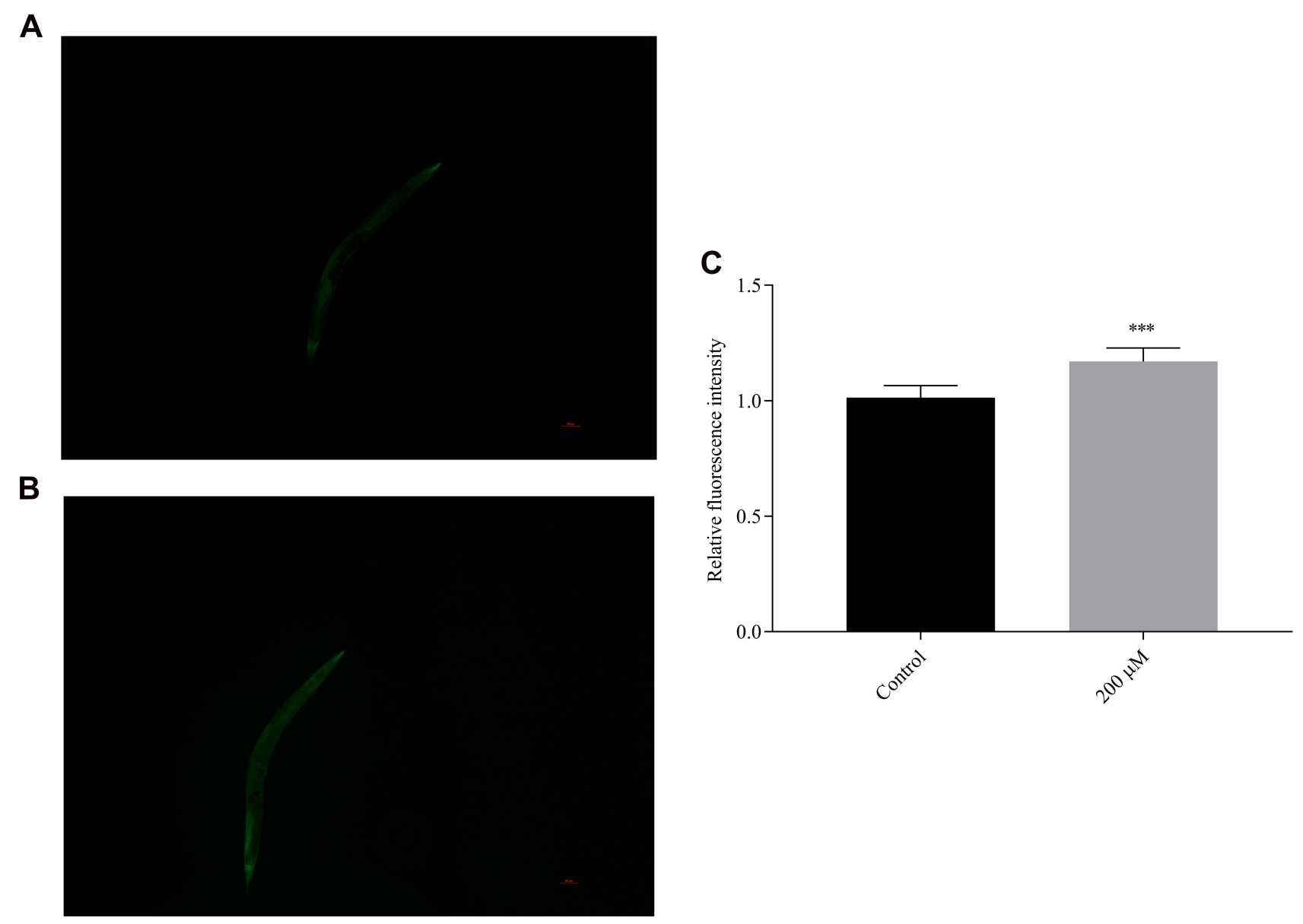

Figure II Fluorescence images showing sod-3::GFP expression in CFI553 C. elegans ((A) control group; (B) $200 \mu$ M group). (C) The sod-3::GFP intensity in the treated CFI553 was quantified and showed significant difference from the control $(* * * p<0.001)$.
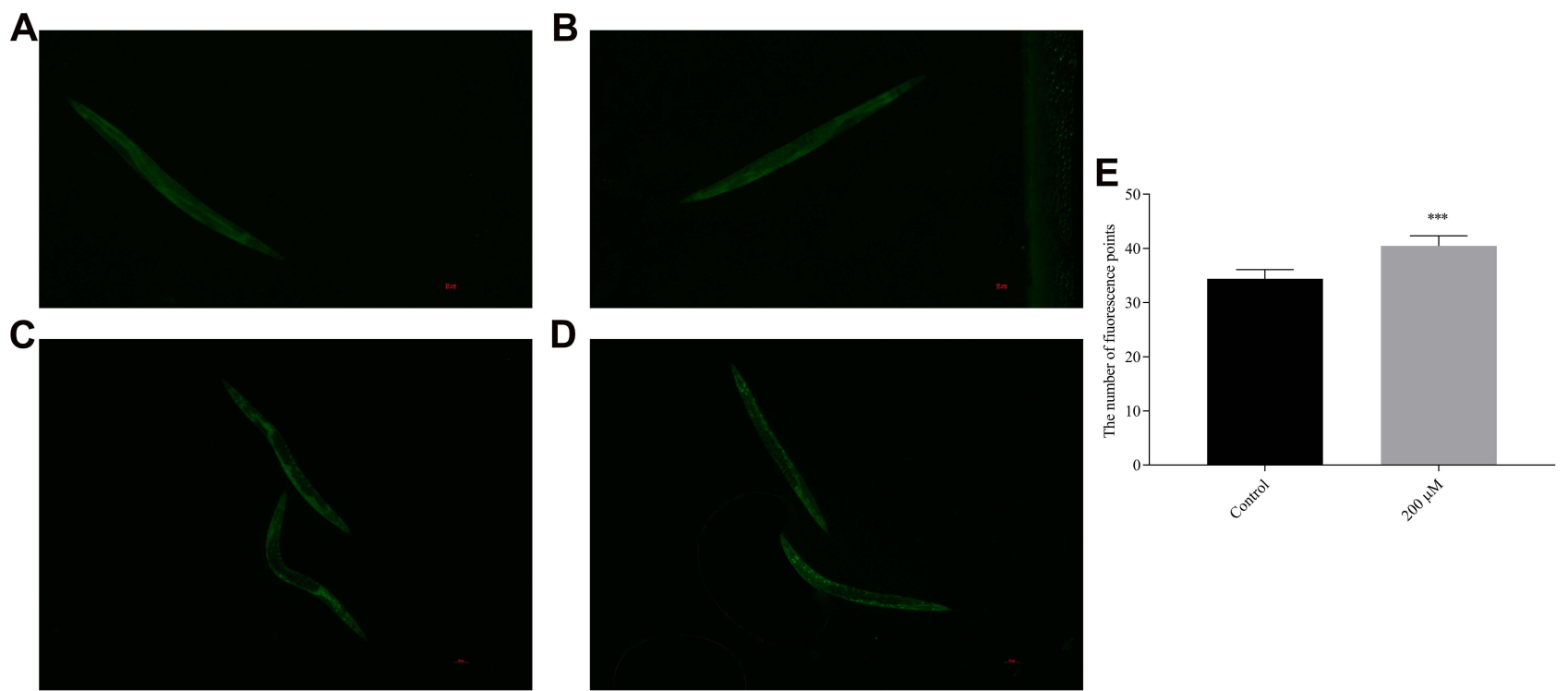

Figure 12 DAF-16::GFP location ((A) control group; (B) pb-3 group; (C) control group $\left(\mathrm{H}_{2} \mathrm{O}_{2}\right)$; (D) pb-3 group $\left.\left(\mathrm{H}_{2} \mathrm{O}_{2}\right)\right)$. (E) Pb-3 induced a significant degree of DAF-16:: GFP in mutant TJ356 worms $(* * * 00.001)$. 
A

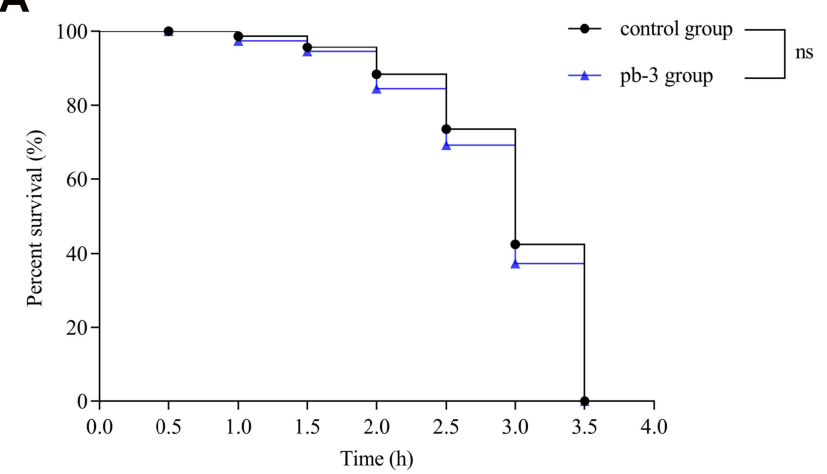

C

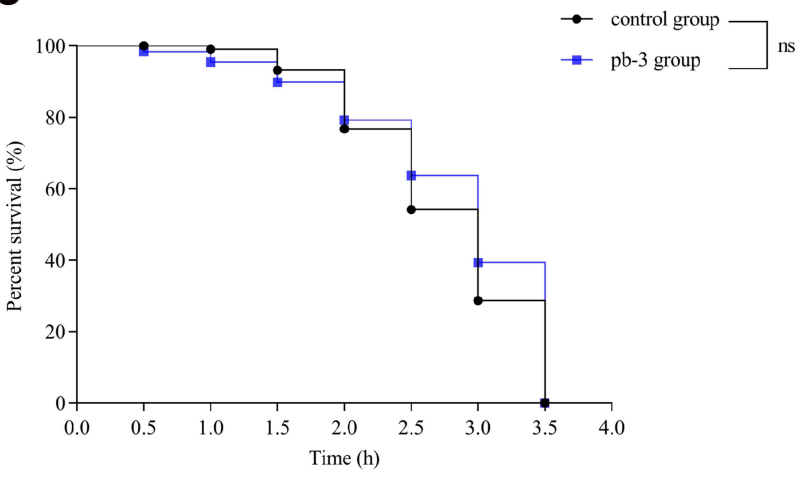

B

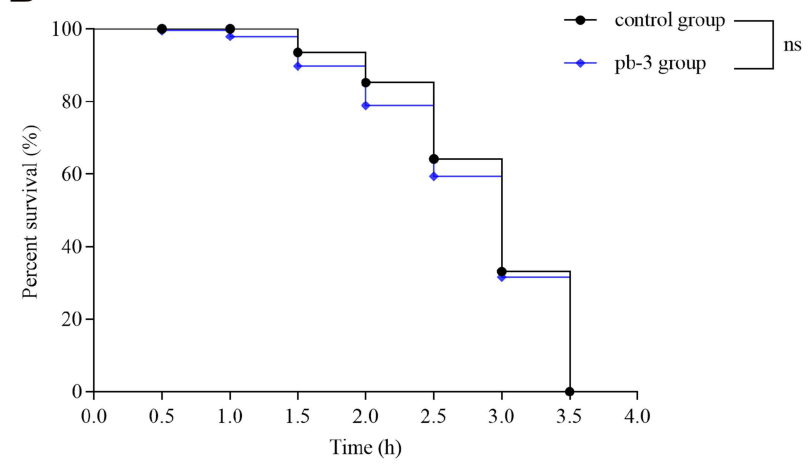

D

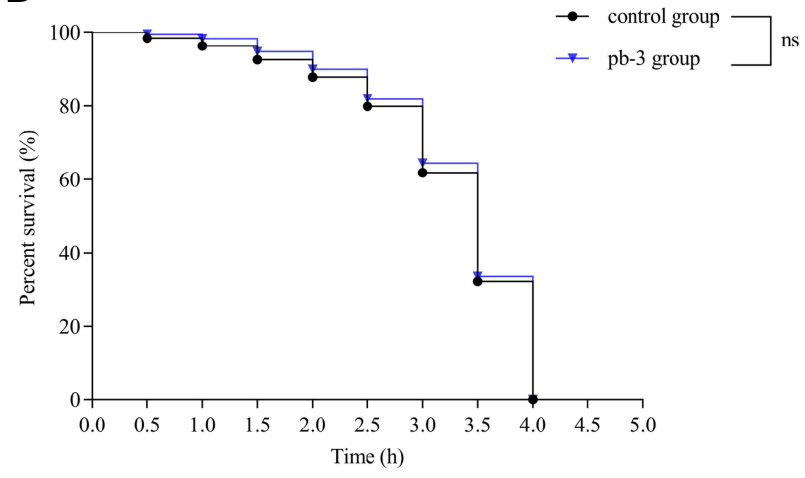

Figure 13 Effect of pb-3 on the survival of the loss-of-function mutant strains daf-I6 (A), hsp/6.2 (B), daf-2 (C) and age-I (D) mutants.

\section{Acknowledgments}

This study was supported by the National Key R\&D Program of China (No.2020071620211) and the Key Programs for Science and Technology Development of Beijing University of Chinese Medicine (No.2020-JYBZDGG-040).

\section{Disclosure}

The authors declare no conflict of interest.

\section{References}

1. Collier TJ, Kanaan NM, Kordower JH. Ageing as a primary risk factor for parkinson's disease: evidence from studies of non-human primates. Nat Rev Neurosci. 2011;12(6):359-366. doi:10.1038/ nrn3039

2. Rathor L, Pandey R. Age-induced diminution of free radicals by Boeravinone $\mathrm{B}$ in Caenorhabditis elegans.. Exp Gerontol. 2018;111:94-106. doi:10.1016/j.exger.2018.07.005

3. Pandey S, Tiwari S, Kumar A, et al. Antioxidant and anti-aging potential of Juniper berry (Juniperus communis L.) essential oil in Caenorhabditis elegans model system. Ind Crops Prod. 2018; 120:113-122. doi:10.1016/j.indcrop.2018.04.066

4. Almeida SM, Nogueira FF, Amaro CC, et al. Antioxidant effect of Resveratrol: change in MAPK cell signaling pathway during the aging process. Arch Gerontol Geriatr. 2021;92:104266. doi:10.1016/j.archger. 2020.104266
5. Yoon DS, Cha DS, Choi Y, et al. MPK-1/ERK is required for the full activity of resveratrol in extended lifespan and reproduction. Aging Cell. 2019;18(1):e12867. doi:10.1111/acel.12867

6. JianQin Z, Xiaoli X, Yuqi Q, et al. Astragaloside IV extends lifespan of Caenorhabditis elegans by improving age-related functional declines and triggering anti-oxidant responses. Rejuvenation Res. 2020;24(2):120-130. doi:10.1089/rej.2020.2312

7. Cordeiro LM, Machado ML, da Silva AF, et al. Rutin protects Huntington's disease through the insulin/IGF1 (IIS) signaling pathway and autophagy activity: study in Caenorhabditis elegans model. Food Chem Toxicol. 2020;141:111323. doi:10.1016/j.fct.20 20.111323

8. Ai-Jun D, Shan-Qing Z, Xiao-Bing H, et al. Current Perspective in the Discovery of Anti-aging Agents from Natural Products. Natural ProdBioprospect. 2017;7(5):335-404. doi:10.1007/ s13659-017-0135-9

9. Rasul A, Millimouno FM, Eltayb WA, et al. Pinocembrin: a novel natural compound with versatile pharmacological and biological activities. Biomed Res Int. 2013;379850. doi:10.1155/ 2013/379850

10. Giri SS, Sen SS, Sukumaran V, et al. Pinocembrin attenuates lipopolysaccharide-induced inflammatory responses in Labeo rohita macrophages via the suppression of the NF- $\mathrm{kB}$ signalling pathway. Fish Shellfish Immunol. 2016;56:459-466. doi:10.1016/j. fsi.2016.07.038

11. Soromou LW, Chu X, Jiang L, et al. In vitro and in vivo protection provided by pinocembrin against lipopolysaccharide-induced inflammatory responses. Int Immunopharmacol. 2012;14(1):66-74. doi:10.1016/j.intimp.2012.06.009

12. Lopez A, Ming DS, et al. Antifungal Activity of Benzoic Acid Derivatives from Piper lanceaefolium. J Nat Prod. 2002;65(1): 62-64. doi:10.1021/np010410g 
13. Suresh kumar MA, Nai M, Hema PS, et al. Pinocembrin triggers Bax-dependent mitochondrial apoptosis in colon cancer cells. Mol Carcinog. 2007;46(3):231-241. doi:10.1002/mc.20272

14. Punvittayagul C, Wongpoomchai R, Taya S, Pompimon W. Effect of pinocembrin isolated from Boesenbergia pandurata on xenobiotic-metabolizing enzymes in rat liver. Drug Metab Lett. 2010;5(1):1-5. doi:10.2174/187231211794455226

15. Hanieh H, Hairul Islam VI, Saravanan S, et al. Pinocembrin, a novel histidine decarboxylase inhibitor with anti-allergic potential in in vitro. Eur J Pharmacol. 2017;814:178-186. doi:10.1016/j.ejphar.2017.08.012

16. Meng F, Liu R, Gao M, et al. Pinocembrin attenuates blood-brain barrier injury induced by global cerebral ischemia-reperfusion in rats. Brain Res. 2011;1391:93-101. doi:10.1016/j.brainres.2011.03.010

17. Shi LL, Chen BN, Gao M, et al. characteristics of therapeutic effect of pinocembrin in transient global brain ischemia/reperfusion rats. Life Sci. 2011;88:521-528. doi:10.1016/j.1fs.2011.01.011

18. Yumin W, Junhong G, Yingchun M, et al. Pinocembrin protects SH-SY5Y cells against MPP+-induced neurotoxicity through the mitochondrial apoptotic pathway. J Mol Neurosci. 2014;53(4):537545. doi:10.1007/s12031-013-0219-x

19. Yang Z-H, Sun X, Yun Q, et al. Uptake characteristics of pinocembrin and its effect on p-glycoprotein at the blood-brain barrier in in vitro cell experiments. J Asian Nat Prod Res. 2012;14(1):14-21. doi:10.1080/10286020.2011.620393

20. de Oliveira MR, Alessandra P, Clarissa Severino G, et al. Pinocembrin Provides Mitochondrial Protection by the Activation of the Erk1/2-Nrf2 Signaling Pathway in SH-SY5Y Neuroblastoma Cells Exposed to Paraquat. Mol Neurobiol. 2017;54(8):6018-6031. doi:10.1007/s12035-016-0135-5

21. Lan X, Wang W, Qiang L, et al. The Natural Flavonoid Pinocembrin: molecular Targets and Potential Therapeutic Applications. Mol Neurobiol. 2016;53(3):1794-1801. doi:10.1007/ s12035-015-9125-2

22. Wei W, Lili Z, Lijun X, et al. Pinocembrin mitigates depressive-like behaviors induced by chronic unpredictable mild stress through ameliorating neuroinflammation and apoptosis. Mol Med. 2020;26(1):53-63. doi:10.1186/s10020-020-00179-x

23. Xiaohui J, Menglu J, Yuqin Y, et al. Synthesis of Novel Baicalein Amino Acid Derivatives and Biological Evaluation as Neuroprotective Agents. Molecules. 2019;24(20):3647-3661. doi:10.3390/molecules24203647

24. Pande SV, Utale PS, Gholse SB, et al. Synthesis and Antibacterial Evaluation of Carboxamide Derivatives of Amino Acids. PharmChem J. 2014;48(1):29-33. doi:10.1007/s11094-014-1040-8

25. Spasova M, Philipov S, Milkova T. Amino acid Derivatives of Aporphinic Alkaloid Glaucine and their antioxidant activity. $A d v$ Exp Med Biol. 2009;611:267-268. doi:10.1007/978-0-387-73657$0 \_120$

26. Yin Z, Wenfei H, Zhang W, et al. Tailor-made amino acid-derived pharmaceuticals approved by the FDA in 2019. Amino Acids. 2020;52(9):1227-1261. doi:10.1007/s00726-020-02887-4

27. Tianshu W, Hongsheng X, Liang X, et al. Caenorhabditis elegans as a complete model organism for biosafety assessments of nanoparticles. Chemosphere. 2019;221:708-726. doi:10.1016/j. chemosphere.2019.01.021

28. Collins James J, Cheng H, Stacie H, et al. The measurement and analysis of age-related changes in Caenorhabditis elegans. WormBook. 2008;1-21. doi:10.1895/wormbook.1.137.1

29. Kalyanaraman B, Darley-Usmar V, Davies KJ. Measuring reactive oxygen and nitrogen species with fluorescent probes: challenges and limitations. Free Radic Biol Med. 2012;52(1):1-6. doi:10.1016/j. freeradbiomed.2011.09.030
30. Christian B, Liang Z, Susannah $H$, et al. TSG $\left(2,3,5,4^{\prime}\right.$ Tetrahydroxystilbene-2-O- $\beta$-D-glucoside) from the Chinese Herb Polygonum multiflorum Increases Life Span and Stress Resistance of Caenorhabditis elegans. Oxid Med Cell Longev. 2015;124357. doi:10.1155/2015/124357

31. Cypser JR, Tedesco P, Johnson TE. Hormesis and aging in Caenorhabditis elegans. Exp Gerontol. 2006;41(10):935-939. doi:10.1016/j.exger.2006.09.004

32. Gelino S, Chang JT, Kumsta C, et al. Intestinal Autophagy Improves Healthspan and Longevity in C. elegans during Dietary Restriction. PLoS Genet. 2016;12(7):e1006135. doi:10.1371/journal.pgen.1006135

33. Skoczy' Nska A, Budzisz ET, Rznadel-Grodzka E, et al. Melanin and lipofuscin as hallmarks of skin aging. Postepy Dermatol Alergol. 2017;34(2):97-103. doi:10.5114/ada.2017.67070

34. Wang YF, Chen C, Wang H, et al. Zhao, Study on the effects of hawthorn fruit extract on aging in Caenorhabditis elegans. Acta Nutrimenta Sin. 2016;38(4):391-396. doi:10.13325/j.cnki.acta.nutr. $\sin .2016 .04 .027$

35. Feng SL, Cheng HR, Xu Z, et al. Thermal stress resistance and aging effects of Panax notoginseng polysaccharides on Caenorhabditis elegans.. Int J Biol Macromol. 2015;81:188-194. doi:10.1016/j. ijbiomac.2015.07.057

36. Avery L, You YJ. C. elegans feeding. WormBook. 2012;1-23. doi:10.1895/wormbook.1.150.1

37. Chamoli M, Singh A, Malik Y, et al. A novel kinase regulates dietary restriction-mediated longevity in Caenorhabditis elegans. Aging Cell. 2014;13(4):641-655. doi:10.1111/acel.12218

38. Zhang W, Zheng B, Deng N, et al. Effects of ethyl acetate fractional extract from Portulaca oleracea L. (PO-EA) on lifespan and healthspan in Caenorhabditis elegans. J Food Sci. 2020;85(12):4367-4376. doi:10.1111/1750-3841.15507

39. Murphy CT, McCarroll SA, Bargmann CI, et al. Genes that act downstream of DAF-16 to influence the lifespan of Caenorhabditis elegans. Nature. 2003;424(6946):277-283. doi:10.1038/nature01789

40. Shi YC, Yu CW, Liao VH, et al. Monascus-fermented dioscorea enhances oxidative stress resistance via DAF-16/FOXO in Caenorhabditis elegans. PLoS One. 2012;7(6):e39515. doi:10.1371/journal.pone.0039515

41. Rea SL, Wu D, Cypser JR, et al. A stress-sensitive reporter predicts longevity in isogenic populations of Caenorhabditis elegans. Nat Genet. 2005;37(8):894-898. doi:10.1038/ng1608

42. Hsu AL, Murphy CT, Kenyon C. Regulation of aging and age-related disease by DAF-16 and heat-shock factor. Science. 2003;300 (5622):1142-1145. doi:10.1126/science.1083701

43. Henderson ST, Johnson TE. daf-16 integrates developmental and environmental inputs to mediate aging in the nematode Caenorhabditis elegans. Current Biology. 2001;11(24):1975-1980. doi:10.1016/S0960-9822(01)00594-2

44. Kenyon C, Libina N, Hsin H, et al. Regulation of the Caenorhabditis elegans longevity protein DAF-16 by insulin/IGF-1 and germline signaling. Nat Genet. 2001;28(2):139-145. doi:10.1038/88850

45. Finch CE, Ruvkun G. The genetics of aging. Annu Rev Genomics Hum Genet. 2001;2:435-462. doi:10.1146/annurev.genom.2.1.435

46. Samuelson AV, Carr CE, Ruvkun G. Gene activities that mediate increased life span of $C$. elegans insulin-like signaling mutants. Genes Dev. 2007;21(22):2976-2994. doi:10.1101/gad.1588907

47. Murphy CT, Hu PJ. Insulin/insulin-like growth factor signaling in $C$. elegans. WormBook. 2013;1-43. doi:10.1895/wormbook.1.164.1 


\section{Publish your work in this journal}

Drug Design, Development and Therapy is an international, peerreviewed open-access journal that spans the spectrum of drug design and development through to clinical applications. Clinical outcomes, patient safety, and programs for the development and effective, safe, and sustained use of medicines are a feature of the journal, which has also been accepted for indexing on PubMed Central. The manuscript management system is completely online and includes a very quick and fair peer-review system, which is all easy to use. Visit http://www. dovepress.com/testimonials.php to read real quotes from published authors.

Submit your manuscript here: https://www.dovepress.com/drug-design-development-and-therapy-journal 